\title{
Review of applications of TLBO algorithm and a tutorial for beginners to solve the unconstrained and constrained optimization problems
}

\author{
R. Venkata Rao*
}

Department of Mechanical Engineering, S.V. National Institute of Technology, Ichchanath, Surat, Gujarat - 395 007, India

\begin{tabular}{l}
\hline C H R O N I C L E \\
\hline Article history: \\
Received June25, 2015 \\
Received in revised format: \\
September 22, 2015 \\
Accepted September 24, 2015 \\
Available online \\
September 25 2015 \\
\hline Keywords: \\
TLBO algorithm \\
Optimization \\
Constrained and unconstrained \\
problems \\
Tutorial \\
\hline
\end{tabular}

A B S T R A C T

The teaching-learning-based optimization (TLBO) algorithm is finding a large number of applications in different fields of engineering and science since its introduction in 2011. The major applications are found in electrical engineering, mechanical design, thermal engineering, manufacturing engineering, civil engineering, structural engineering, computer engineering, electronics engineering, physics, chemistry, biotechnology and economics. This paper presents a review of applications of TLBO algorithm and a tutorial for solving the unconstrained and constrained optimization problems. The tutorial is expected to be useful to the beginners.

(C) 2016 Growing Science Ltd. All rights reserved.

\section{Introduction}

The population based heuristic algorithms have two important groups: evolutionary algorithms (EA) and swarm intelligence (SI) based algorithms. Some of the recognized evolutionary algorithms are: Genetic Algorithm (GA), Evolution Strategy (ES), Evolution Programming (EP), Differential Evolution (DE), Bacteria Foraging Optimization (BFO), Artificial Immune Algorithm (AIA), etc. Some of the well-known swarm intelligence based algorithms are: Particle Swarm Optimization (PSO), Shuffled Frog Leaping (SFL), Ant Colony Optimization (ACO), Artificial Bee Colony (ABC), Fire Fly (FF) algorithm, etc. Besides the evolutionary and swarm intelligence based algorithms, there are some other algorithms which work on the principles of different natural phenomena. Some of them are: Harmony Search algorithm (HSA), Gravitational Search algorithm (GSA), Biogeography-Based Optimization (BBO), Grenade Explosion Method (GEM), etc. (Rao \& Patel, 2012).

All the evolutionary and swarm intelligence based algorithms are probabilistic algorithms and require common controlling parameters like population size, number of generations, elite size, etc. Besides the

\footnotetext{
* Corresponding author.

E-mail address: ravipudirao@gmail.com (R. Venkata Rao) 
common control parameters, different algorithms require their own algorithm-specific control parameters. For example, GA uses mutation probability, crossover probability, selection operator; PSO uses inertia weight, social and cognitive parameters; ABC uses number of onlooker bees, employed bees, scout bees and limit; HS algorithm uses harmony memory consideration rate, pitch adjusting rate, and the number of improvisations. Similarly, the other algorithms such as ES, EP, DE, BFO, AIA, SFL, ACO, etc. need the tuning of respective algorithm-specific parameters. The proper tuning of the algorithm-specific parameters is a very crucial factor which affects the performance of the above mentioned algorithms. The improper tuning of algorithm-specific parameters either increases the computational effort or yields the local optimal solution. Considering this fact, Rao et al. (2011) introduced the teaching-learning-based optimization (TLBO) algorithm which does not require any algorithm-specific parameters. The TLBO algorithm requires only common controlling parameters like population size and number of generations for its working. The TLBO algorithm has gained wide acceptance among the optimization researchers (Rao, 2015). The working of TLBO algorithm is explained in the next section.

\section{TLBO algorithm}

The working of TLBO is divided into two parts, 'Teacher phase' and 'Learner phase'. Working of both these phases is explained below (Rao, 2015).

\subsection{Teacher phase}

It is the first part of the algorithm where learners learn through the teacher. During this phase a teacher tries to increase the mean result of the class in the subject taught by him or her depending on his or her capability. At any iteration $i$, assume that there are ' $m$ ' number of subjects (i.e. design variables), ' $n$ ' number of learners (i.e. population size, $k=1,2, \ldots, n)$ and $M_{j, i}$ be the mean result of the learners in a

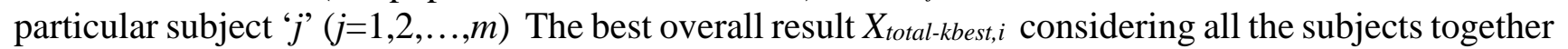
obtained in the entire population of learners can be considered as the result of best learner kbest. However, as the teacher is usually considered as a highly learned person who trains learners so that they can have better results, the best learner identified is considered by the algorithm as the teacher. The difference between the existing mean result of each subject and the corresponding result of the teacher for each subject is given by,

$$
\text { Difference_Mean }{ }_{j, k, i}=r_{i}\left(X_{j, k b e s t, i}-T_{F} M_{j, i}\right) \text {, }
$$

where, $X_{j, k b e s t, i}$ is the result of the best learner in subject $j . T_{F}$ is the teaching factor which decides the value of mean to be changed, and $r_{i}$ is the random number in the range $[0,1]$. Value of $T_{F}$ can be either 1 or 2 . The value of $T_{F}$ is decided randomly with equal probability as,

$$
T_{F}=\text { round }[1+\operatorname{rand}(0,1)\{2-1\}] \text {, }
$$

Where $T_{F}$ is not a parameter of the TLBO algorithm. The value of $T_{F}$ is not given as an input to the algorithm and its value is randomly decided by the algorithm using Eq. (2). After conducting a number of experiments on many benchmark functions, it is concluded that the algorithm performs better if the value of $T_{F}$ is between 1 and 2 . However, the algorithm is found to perform much better if the value of TF is either 1 or 2 and hence to simplify the algorithm, the teaching factor is suggested to take either 1 or 2 depending on the rounding up criteria given by Eq. (2). Based on the Difference_Mean ${ }_{j, k, i}$, the existing solution is updated in the teacher phase according to the following expression.

$$
X_{j, k, i}^{\prime}=X_{j, k, i}+\text { Difference_Mean }{ }_{j, k, I} \text {, }
$$

Where, $X_{j, k, i}^{\prime}$ is the updated value of $X_{j, k, i}$. $\quad X_{j, k, i}^{\prime}$ is acceptedif it gives better function value. All the accepted function values at the end of the teacher phase are maintained and these values become the input to the learner phase. The learner phase depends upon the teacher phase. 


\subsection{Learner phase}

It is the second part of the algorithm where learners increase their knowledge by interaction among themselves. A learner interacts randomly with other learners for enhancing his or her knowledge. A learner learns new things if the other learner has more knowledge than him or her. Considering a population size of ' $n$ ', randomly select two learners $\mathrm{P}$ and $\mathrm{Q}$ such that $X_{\text {total-P, } i} \neq X_{\text {total-Q, }}$ (where, $X_{\text {total }}$ -

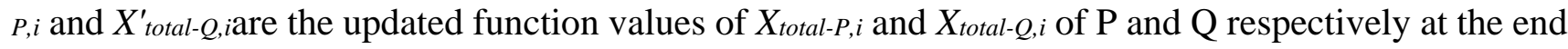
of teacher phase)

$$
\begin{aligned}
& X_{j, P, i}^{\prime \prime}=X_{j, P, i}^{\prime}+r_{i}\left(X_{j, P, i^{-}}^{\prime} X_{j, Q, i}^{\prime}\right), \text { If } X_{\text {total-P, },<}^{\prime}<X_{\text {total-Q,i }}^{\prime} \\
& X_{j, P, i}^{\prime \prime}=X_{j, P, i}^{\prime}+r_{i}\left(X_{j, Q, i}^{\prime}-X_{j, P, i}^{\prime}\right), \text { If } X_{\text {total-Q, },<}<X_{\text {total-P,i }}^{\prime}
\end{aligned}
$$

Where, $X_{j, P, I}^{\prime}$ is accepted if it gives a better function value. The Eq. (4) and Eq. (5) are for minimization problems. In the case of maximization problems, the Eqs. (6-7) are used.

$$
\begin{gathered}
X_{j, P, i}^{\prime \prime}=X_{j, P, i}^{\prime}+r_{i}\left(X_{j, P, i-}^{\prime} X_{j, Q, i}^{\prime}\right), \text { If } X_{\text {total-Q,i }}^{\prime}<X_{\text {total-P,I, }}^{\prime} \\
X_{j, P, i}^{\prime \prime}=X_{j, P, i}^{\prime}+r_{i}\left(X_{j, Q, i}^{\prime}-X_{j, P, i}^{\prime}\right), \text { If } X_{\text {total-P, }, i}^{\prime}<X_{\text {total-Q,I. }}^{\prime}
\end{gathered}
$$

The next section presents a tutorial on solving the unconstrained and constrained optimization problems using the TLBO algorithm

\section{Tutorial for solving the unconstrained and constrained optimization problems}

\subsection{Unconstrained optimization problems}

To demonstrate the working of TLBO algorithm for solving the unconstrained optimization problems. A benchmark function of Himmelblau is considered. The objective function is to find out the values of $x_{1}$ and $x_{2}$ that minimize the Himmelblau function.

Benchmark function: Unconstrained Himmelblau function

$$
\begin{aligned}
& \min f\left(x_{i}\right)=\left(x_{1}^{2}+x_{2}-11\right)^{2}+\left(x_{1}+x_{2}^{2}-7\right)^{2} \\
& \text { subject to } \\
& -5 \leq x_{1}, x_{2} \leq 5
\end{aligned}
$$

The known solution to this benchmark function is 0 for $x_{1}=3$ and $x_{2}=2$. Now to demonstrate the TLBO algorithm, let us assume a population size of 5 (i.e. number of learners), two design variables $x_{1}$ and $x_{2}$ (i.e. number of subjects) and one iteration as the termination criterion. The initial population is randomly generated within the ranges of the variables and the corresponding values of the objective function are shown in Table 1.

\section{Table 1}

Initial population

\begin{tabular}{lccc}
\hline Learner & $x_{1}$ & $x_{2}$ & $f(x)$ \\
\hline 1 & 3.22 & 0.403 & 13.13922 \\
2 & 0.191 & 2.289 & 77.71054 \\
3 & 3.182 & 0.335 & 14.02423 \\
4 & 1.66 & 4.593 & 261.57319 \\
5 & 2.214 & 0.867 & 43.64116 \\
\hline Mean & 2.093 & 1.697 & \\
\hline
\end{tabular}

The mean values of $x_{1}$ and $x_{2}$ are also shown. As it is a minimization function, the lowest value of $f(x)$ is considered as the best learner (and is considered as equivalent to teacher).Now the teacher tries to improve the mean result of the class. Assuming random numbers $r_{1}=0.25$ for $x_{1}$ and $r_{2}=0.43$ for $x_{2}$, and $T_{f}=1$, the difference_mean values for $x_{1}$ and $x_{2}$ are calculated as,

difference_mean $\left(x_{1}\right)=0.25 *(3.22-2.093)=0.28175$

difference_mean $\left(x_{2}\right)=0.43 *(0.403-1.697)=-0.55642$ 
The value of difference_mean $\left(x_{1}\right)$ is added to all the values under the $x_{1}$ column and the value of difference_mean $\left(x_{2}\right)$ is added to all the values under the $x_{2}$ column of Table 1 . Table 2 shows the new values of $x_{1}$ and $x_{2}$ and the corresponding values of the objective function.

Table 2

New values of the variables and the objective function (teacher phase)

\begin{tabular}{lll}
\hline$x_{1}$ & $x_{2}$ & $f(x)$ \\
\hline 3.50175 & -0.15342 & 13.30313 \\
0.47275 & 1.73258 & 94.22118 \\
3.46375 & -0.221 & 12.76507 \\
1.94175 & 4.03658 & 136.4370 \\
2.49575 & 0.31058 & 39.32602 \\
\hline
\end{tabular}

Now, the values of $f(x)$ of Tables 1 and 2 are compared and the best values of $f(x)$ are considered and placed in Table 3. This completes the teacher phase of the TLBO algorithm.

\section{Table 3}

Updated values of the variables and the objective function based on fitness comparison (teacher phase)

\begin{tabular}{lll}
\hline$x_{1}$ & $x_{2}$ & $f(x)$ \\
\hline 3.22 & 0.403 & 13.13922 \\
0.191 & 2.289 & 77.71054 \\
3.46375 & -0.221 & 12.76507 \\
1.94175 & 4.03658 & 136.4370 \\
2.49575 & 0.31058 & 39.32602 \\
\hline
\end{tabular}

Now, the learner phase starts and any student can interact with any other student for knowledge transfer. This interaction can be done in a random manner. In this example, interactions between learners 1 and 2, 2 and 5, 3 and 1, 4 and 5, and 5 and 4 are considered. It is to be noted that every learner has to interact with any other learner. That is why, in this example, 5 interactions are considered (i.e. one interaction for each learner). Table 4 shows the new values of $x_{1}$ and $x_{2}$ for the learners after the interactions and considering random numbers $r_{1}=0.47$ for $x_{1}$ and $r_{2}=0.33$ for $x_{2}$. For example, the new values of $x_{1}$ and $x_{2}$ for learner 1 are calculated as explained below.

As it is a minimization function, the value of $f(x)$ is better for learner 1 as compared to that of learner 2 and hence the knowledge transfer is from learner 1 to learner 2 . Hence the new values of $x_{1}$ and $x_{2}$ for learner 1 are calculated as,

$\left(x_{1}\right)$ new for learner $1=3.22+0.47(3.22-0.191)=4.64363$

$\left(x_{2}\right)$ new for learner $1=0.403+0.33(0.403-2.289)=-0.21938$

Similarly, the new values of $x_{1}$ and $x_{2}$ for learner 2 are calculated as explained below.

As it is a minimization function, the value of $f(x)$ is better for learner 5 as compared to that of learner 2 and hence the knowledge transfer is from learner 5 to learner 2 . Hence the new values of $x_{1}$ and $x_{2}$ for learner 2 are calculated as,

$\left(x_{1}\right)$ new for learner $2=0.191+0.47(2.49575-0.191)=1.27423$

$(x 2)$ new for learner $2=2.289+0.33(0.31058-2.289)=1.63612$

Table 4

New values of the variables and the objective function (learner phase)

\begin{tabular}{llll}
\hline$x_{1}$ & $x_{2}$ & $f(x)$ & Interaction \\
\hline 4.64363 & -0.21938 & 112.32465 & $1 \& 2$ \\
1.27423 & 1.63612 & 69.20665 & 2 \& 5 \\
3.57831 & -0.42692 & 12.39108 & 3 \& 1 \\
2.20213 & 2.807 & 20.67471 & $4 \& 5$ \\
2.75613 & -0.919 & 30.24144 & $5 \& 4$ \\
\hline
\end{tabular}


Now, the values of $f(x)$ of Tables 3 and Table 4 are compared and the best values of $f(x)$ are considered and placed in Table 5 .

Table 5

Updated values of the variables and the objective function based on fitness comparison (learner phase)

\begin{tabular}{lll}
\hline$x_{1}$ & $x_{2}$ & $f(x)$ \\
\hline 3.22 & 0.403 & 13.13922 \\
1.27423 & 1.63612 & 69.20665 \\
3.57831 & -0.42692 & 12.39108 \\
2.20213 & 2.807 & 20.67471 \\
2.75613 & -0.919 & 30.24144 \\
\hline
\end{tabular}

This completes the learner phase and one iteration of the TLBO algorithm. The value of $f(x)$ is reduced from 13.13922 at the beginning of iteration to 12.39108 at the end of first iteration. Increasing the number of iterations will soon find the value of $f(x)$ reaching the known solution of 0 for $x_{1}=3$ and $x_{2}$ $=2$.

\subsection{Constrained optimization problems}

Now a constrained benchmark function of Himmelblau is considered. The objective function is to find out the values of $x_{1}$ and $x_{2}$ that minimize the Himmelblau function subject to the given constraints.

Benchmark function: Constrained Himmelblau function

$$
\begin{aligned}
& \min f\left(x_{i}\right)=\left(x_{1}^{2}+x_{2}-11\right)^{2}+\left(x_{1}+x_{2}^{2}-7\right)^{2} \\
& \text { subject to } \\
& g_{1}(x)=26-\left(x_{1}-5\right)^{2}-x_{2}^{2} \geq 0 \\
& g_{2}(x)=20-4 x_{1}-x_{2} \geq 0 \\
& -5 \leq x_{1}, x_{2} \leq 5
\end{aligned}
$$

The known solution to this benchmark function is 0 for $x_{1}=3$ and $x_{2}=2$ and $g_{1}(x)=18$ and $g_{2}(x)=6$. Now to demonstrate the TLBO algorithm, let us assume a population size of 5 (i.e. number of learners), two design variables $x_{1}$ and $x_{2}$ (i.e. number of subjects) and one iteration as the termination criterion. The initial population is randomly generated within the ranges of the variables and the corresponding values of the objective function are shown in Table 6 . The randomly generated values of $x_{1}$ and $x_{2}$ in Table 6 are same as those in Table 1 and this is just for convenience in demonstration. In normal practice, these can be any of the randomly generated values within the given ranges of the variables. The mean values of $x_{1}$ and $x_{2}$ are also shown. As it is a minimization function, the lowest value of $f(x)$ is considered as the best learner (and is considered as equivalent to teacher). If the constraints are violated then penalties are assigned to the objective function. There are many methods reported in the literature to assign the penalties and in this example the penalty $p_{1}$ for violation of $g_{1}(x)$ is considered as $10 *\left(g_{1}(x)\right)^{2}$ and the penalty $p_{2}$ for violation of $g_{2}(x)$ is considered as $10^{*}\left(g_{2}(x)\right)^{2}$. As it is a minimization problem, the values of penalties are added to the value of the objective function $f(x)$ and the fitness function is $f^{\prime}(x)=f(x)+10^{*}\left(g_{1}(x)\right)^{2}+10^{*}\left(g_{2}(x)\right)^{2}$. The function $f^{\prime}(x)$ is called the pseudoobjective function. It may be noted that $10^{*}\left(g_{1}(x)\right)^{2}$ is used as the penalty function in this example for the violation in constraint $g_{1}(x)$ and $10^{*}\left(g_{2}(x)\right)^{2}$ is used as the penalty function for the violation in constraint $g_{2}(x)$. However, this is only for demonstration. Normally, higher penalties are desirable and one may use $50 *\left(g_{1}(x)\right)^{2}$ or $100 *\left(g_{1}(x)\right)^{2}$ or $500 *\left(g_{1}(x)\right)^{2}$ or any such penalty for violation of $g_{1}(x)$ and $50 *\left(g_{2}(x)\right)^{2}$ or $100 *\left(g_{2}(x)\right)^{2}$ or $500 *\left(g_{2}(x)\right)^{2}$ or any such penalty for violation of $g_{2}(x)$. The assignment of penalties for violations depends upon the designer/decision maker/user. Sometimes, the penalty functions assigned may be different for different constraints depending upon the application as decided by the designer/decision maker/user. Also, penalty may be increased considering how many constraints 
of a given problem are violated. The mean values of $x_{1}$ and $x_{2}$ are also shown in Table 6 . As it is a minimization function, the lowest value of $f^{\prime}(x)$ is considered as the best learner.

Table 6

Initial population

\begin{tabular}{llllllll}
\hline$x_{1}$ & $x_{2}$ & $f(x)$ & $g_{1}(x)$ & $p_{1}$ & $g_{2}(x)$ & $p_{2}$ & $f^{\prime}(\mathrm{x})$ \\
\hline 3.22 & 0.403 & 13.13922 & 22.66919 & 0 & 6.7170 & 0 & 13.13922 \\
0.191 & 2.289 & 77.71054 & -2.36600 & 55.97956 & 16.9470 & 0 & 133.6901 \\
3.182 & 0.335 & 14.02423 & 22.58265 & 0 & 6.9370 & 0 & 14.02423 \\
1.66 & 4.593 & 261.57319 & -6.25124 & 390.78001 & 8.7670 & 0 & 652.3532 \\
2.214 & 0.867 & 43.64116 & 17.48651 & 0 & 10.2770 & 0 & 43.64116 \\
\hline Mean= 2.093 & Mean=1.697 & & & & & \\
\hline
\end{tabular}

Now the teacher tries to improve the mean result of the class. Assuming random numbers $r_{1}=0.25$ for $x_{1}$ and $r_{2}=0.43$ for $x_{2}$ and $T_{f}=1$, the difference_mean values for $x_{1}$ and $x_{2}$ are calculated as,

difference_mean $\left(x_{1}\right)=0.25 *(3.22-2.093)=0.28175$

difference_mean $\left(x_{2}\right)=0.43 *(0.403-1.697)=-0.55642$

The values of difference_mean $\left(x_{1}\right)$ and difference_mean $\left(x_{2}\right)$ are added to the values under the $x_{1}$ and $x_{2}$ columns respectively of Table 6 . Table 7 shows the new values of $x_{1}$ and $x_{2}$, penalties and the corresponding values of the objective function and pseudo-objective function.

Table 7

New values of the variables, objective function and the penalties (teacher phase)

\begin{tabular}{llllllll}
\hline$x_{1}$ & $x_{2}$ & $f(x)$ & $g_{1}(x)$ & $p_{1}$ & $g_{2}(x)$ & $p_{2}$ & $f^{\star}(\mathrm{x})$ \\
\hline 3.50175 & -0.15342 & 13.30313 & 23.73170 & 0 & 6.14642 & 0 & 13.30313 \\
0.47275 & 1.73258 & 94.22118 & 2.50217 & 0 & 16.37642 & 0 & 94.22118 \\
3.46375 & -0.22142 & 12.76312 & 23.59090 & 0 & 6.36642 & 0 & 12.76312 \\
1.94175 & 4.03658 & 136.4370 & 0.35312 & 0 & 8.19642 & 0 & 136.4370 \\
2.49575 & 0.31058 & 39.32602 & 19.63227 & 0 & 9.70642 & 0 & 39.32602 \\
\hline
\end{tabular}

Now, the values of $f^{\prime}(x)$ of Tables 6 and 7 are compared and the best values of $f^{\prime}(x)$ are considered and placed in Table 8. This completes the teacher phase of the TLBO algorithm.

\section{Table 8}

Updated values of the variables, objective function and the penalties based on fitness comparison (teacher phase)

\begin{tabular}{llllllll}
\hline$x_{1}$ & $x_{2}$ & $f(x)$ & $g_{1}(x)$ & $p_{1}$ & $g_{2}(x)$ & $p_{2}$ & $f^{\prime}(\mathrm{x})$ \\
\hline 3.22 & 0.403 & 13.13922 & 22.66919 & 0 & 6.7170 & 0 & 13.13922 \\
0.47275 & 1.73258 & 94.22118 & 2.50217 & 0 & 16.37642 & 0 & 94.22118 \\
3.46375 & -0.22142 & 12.76312 & 23.59090 & 0 & 6.36642 & 0 & 12.76312 \\
1.94175 & 4.03658 & 136.4370 & 0.35312 & 0 & 8.19642 & 0 & 136.4370 \\
2.49575 & 0.31058 & 39.32602 & 19.63227 & 0 & 9.70642 & 0 & 39.32602 \\
\hline
\end{tabular}

Now, the learner phase starts and any student can interact with any other student for knowledge transfer. This interaction can be done in a random manner. In this example, interactions between learners 1 and 2, 2 and 5, 3 and 1, 4 and 5, and 5 and 4 are considered. Table 9 shows the new values of $x_{1}$ and $x_{2}$ for the learners after the interactions and considering random numbers $r_{1}=0.47$ for $x_{1}$ and $r_{2}=0.33$ for $x_{2}$. 
Table 9

New values of the variables, objective function and the penalties (learner phase)

\begin{tabular}{lllllllll}
\hline$x_{1}$ & $x_{2}$ & $f(x)$ & $g_{1}(x)$ & $p_{1}$ & $g_{2}(x)$ & $p_{2}$ & $f^{\prime}(\mathrm{x})$ & Interaction \\
\hline 4.51120 & -0.03576 & 92.96006 & 25.75979 & 0 & 1.99096 & 0 & 92.96006 & $1 \& 2$ \\
1.42356 & 1.26332 & 75.29060 & 11.61309 & 0 & 13.04244 & 0 & 75.29060 & $2 \& 5$ \\
3.57831 & -0.42747 & 12.38652 & 23.79606 & 0 & 6.11423 & 0 & 12.38652 & $3 \& 1$ \\
2.20213 & 2.807 & 20.67471 & 10.29267 & 0 & 8.38448 & 0 & 20.67471 & $4 \& 5$ \\
2.75613 & -0.919 & 30.24144 & 20.12048 & 0 & 9.89448 & 0 & 30.24144 & $5 \& 4$ \\
\hline
\end{tabular}

Now, the values of $f^{\prime}(x)$ of Tables 8 and 9 are compared and the best values of $f^{\prime}(x)$ are considered and are placed in Table 10.

\section{Table 10}

Updated values of the variables, objective function and the penalties based on fitness comparison

\begin{tabular}{llllllll}
\hline$x_{1}$ & $x_{2}$ & $f(x)$ & $g_{1}(x)$ & $p_{1}$ & $g_{2}(x)$ & $p_{2}$ & $f^{\prime}(\mathrm{x})$ \\
\hline 3.22 & 0.403 & 13.13922 & 22.66919 & 0 & 6.7170 & 0 & 13.13922 \\
1.42356 & 1.26322 & 75.29060 & 11.61309 & 0 & 13.04244 & 0 & 75.29060 \\
3.57831 & -0.42747 & 12.38652 & 23.79606 & 0 & 6.11423 & 0 & 12.38652 \\
2.20213 & 2.807 & 20.67471 & 10.29267 & 0 & 8.38448 & 0 & 20.67471 \\
2.75613 & -0.919 & 30.24144 & 20.12048 & 0 & 9.89448 & 0 & 30.24144 \\
\hline
\end{tabular}

This completes the learner phase and one iteration of the TLBO algorithm. The value of $f^{\prime}(x)$ is reduced from 13.13922 at the beginning of iteration to 12.38652 at the end of first iteration. Increasing the number of iterations will soon find the value of $f^{\prime}(x)$ reaching the known solution of 0 for $x_{1}=3, x_{2}=$ $2, g_{1}(x)=18$ and $g_{2}(x)=6$.

The above two examples are only to demonstrate how TLBO algorithm works. The user may write a computer program for executing the TLBO algorithm for solving the unconstrained and constrained optimization problems. Furthermore, it is to be noted that in the case of maximization problems, the best value means the maximum value of the objective function and the calculations are to be proceeded accordingly in the teacher and learner phases. The values of penalties are to be subtracted from the objective function in the case of maximization problems (i.e. $\left.f^{\prime}(x)=f(x)-10^{*}\left(g_{1}(x)\right)^{2}-10^{*}\left(g_{2}(x)\right)^{2}\right)$.

\section{Review of applications of TLBO algorithm}

The teaching-learning-based optimization (TLBO) algorithm is finding a large number of applications in different fields of engineering and science since its introduction in 2011 by Rao et al. (2011). Tables 11 to 15 present the details of research papers up to the date of publication of this paper and arranged in alphabetical order of the authors. Efforts are put in to list 200 papers related to TLBO algorithm and there may be few more papers published in conferences and journals.

\section{Table 11}

Research papers published in the year 2011

\begin{tabular}{|c|c|c|}
\hline S.No. & Authors & Work carried out \\
\hline 1. & Rao et al. (2011) & $\begin{array}{l}\text { TLBO algorithm was proposed for solving the constrained } \\
\text { mechanical design optimization problems }\end{array}$ \\
\hline 2. & Rao and Savsani (2011) & $\begin{array}{l}\text { Multiobjective design optimization of a robot gripper was attempted } \\
\text { using TLBO algorithm. }\end{array}$ \\
\hline
\end{tabular}




\section{Table 12}

Research papers published in the year 2012

\begin{aligned} \hline S.No. & \multicolumn{1}{c}{ Authors } \\ \hline 3. & Amiri (2012) \\ \hline 5. & Baghlani and Makiabadi (2012) \\ \hline 6. & Črepinšek et al. (2012) \\ \hline 7. & Gonzalez-Alvarez et al. (2012) \\ & \\ 8. & Kundu et al. (2012) \end{aligned}

TLBO was proposed to solve the clustering problem.

TLBO algorithm was used for shape and size optimization of truss structures with dynamic frequency constraints.

Cooperative co-evolutionary TLBO algorithm with a modified exploration strategy for large scale global optimization was proposed. Presented a note on TLBO algorithm.

The Multiobjective Teaching-Learning-Based Optimization (MOTLBO) was used for solving one of the most important optimization problems in Bioinformatics, the Motif Discovery Problem (MDP).

Proposed a swarm-based niching technique and the results were compared with those obtained by using other algorithms such as SCMA-ES, ShDE, CDE, SDE, SPSO, FERPSO and lbest-PSO variants with ring-topology.

9. Mohapatra et al. (2012) Proposed a new learner stage based on the mutation strategy. The algorithm was applied for optimal placement of capacitors in a distribution network.

10. Niknam et al. (2012a) Teacher and learner phases were modified. The performance of the modified TLBO algorithm was tested on a 70-bus distribution network.

11. Niknam et al., (2012b) Proposed a stochastic model for optimal energy management with the goal of cost and emission minimization. An improved multiobjective TLBO algorithm was implemented to yield the best expected Pareto optimal front.

12. Rajasehkar et al. (2012) Proposed the Elitist Teaching Learning Oppositional Based (ETLOBA) algorithm in order to enhance the accuracy of the TLBO algorithm. The results were compared with those obtained using HS, Improved Bees Algorithm (IBA) and ABC algorithms

13. Ramanand et al. (2012)

Proposed brain-storming incorporated TLBO algorithm for solving electric power dispatch problems.

14. Rao et al. (2012a)

Compared the performance of the TLBO algorithm with the well known optimization algorithms such as GA, ABC, PSO, HS, DE, Hybrid-PSO, etc. by experimenting with different benchmark problems.

15. Rao et al. (2012b) Attempted unconstrained and constrained real parameter optimization problems.

16. Rao and Patel (2012)

Introduced the concept of elitism in the TLBO algorithm and investigated its effecton the performance of the algorithm for the 35 constrained optimization problems.

17. Rao and Savsani (2012)

Presented mechanical design optimization using advanced optimization techniques including TLBO algorithm.

18. Rasoul et al. (2012)

Proposed a modified TLBO algorithm to solve the multiobjective windthermal economic emission dispatch problem.

19. Satapathy and Naik (2012) Proposed a modified TLBO algorithm by incorporating a random weighted differential vector. Comparisons were made with those of OEA, HPSO-TVAC, CLPSO, APSO and variants of DE such as JADE, jDE and SaDE and different variants of ABC.

20. Toğan (2012) Applied the TLBO algorithm for the design optimization of planar steel frames. The results of the TLBO were compared to those of the GA, ACO, harmony search (HS) and the improved ant colony optimization (IACO) 
Table 13

Research papers published in the year 2013

\begin{tabular}{|c|c|c|}
\hline S.No. & Authors & Work carried out \\
\hline 21. & Cheng (2013) & TLBO was used to pick characteristic oligonucleotide primers. \\
\hline 22. & Daljit and Ranjit (2013) & Designed IIR based digital hearing aids using TLBO algorithm. \\
\hline 23. & Dede (2013) & $\begin{array}{l}\text { Used TLBO algorithm for the optimum design of grillage systems based on } \\
\text { the LRFD-AISC (Load and Resistance Factor Design-American Institute of } \\
\text { Steel Construction). }\end{array}$ \\
\hline 24. & $\begin{array}{l}\text { Degertekin and Hayalioglu } \\
\text { (2013) }\end{array}$ & $\begin{array}{l}\text { Applied the TLBO algorithm for optimization of truss structures. The } \\
\text { validity of the method was demonstrated by the four design examples. }\end{array}$ \\
\hline 25. & García and Mena (2013) & $\begin{array}{l}\text { Proposed TLBO algorithm to determine the optimal placement and size of } \\
\text { Distributed Generation (DG) units in distribution systems. }\end{array}$ \\
\hline 26. & Jiang and Zhou (2013) & $\begin{array}{l}\text { Proposed a hybrid differential evolution and TLBO (hDE-TLBO) algorithm } \\
\text { to solve the multiobjective short-term optimal hydro-thermal scheduling. }\end{array}$ \\
\hline 27. & Krishanand et al. (2013) & $\begin{array}{l}\text { Proposed a hybrid self-evolving algorithm with its application to a nonlinear } \\
\text { optimal power flow problem with the focus on the minimization of the fuel } \\
\text { costs of the thermal units }\end{array}$ \\
\hline 28. & Kumar (2013) & Applied for solving constrained mechanical design problems. \\
\hline 29. & Li et al. (2013) & $\begin{array}{l}\text { Proposed an ameliorated TLBO algorithm (A-TLBO) in order to improve } \\
\text { the solution quality and to quicken the convergence speed of TLBO. }\end{array}$ \\
\hline 30. & Makiabadi et al. (2013) & Optimal design of truss bridges using TLBO algorithm wascarried out. \\
\hline 31. & Mandal and Roy (2013) & $\begin{array}{l}\text { Incorporated a quasi-opposition based learning concept in original TLBO } \\
\text { algorithm in order to accelerate the convergence speed and to improve } \\
\text { solution quality. }\end{array}$ \\
\hline 32. & Medina et al. (2013) & $\begin{array}{l}\text { Proposed a Multiobjective Teaching Learning Algorithm based on } \\
\text { Decomposition (MOTLA/D). The performance of the MOTLA/D was tested } \\
\text { on three systems and the results were compared with those obtained using } \\
\text { other multiobjective algorithm based on decomposition. }\end{array}$ \\
\hline 33. & Niknam et al. (2013) & $\begin{array}{l}\text { Introduced a modified phase based on the self adaptive mechanism in the } \\
\text { TLBO algorithm in order to achieve a balance between the exploration and } \\
\text { exploitation capabilities of the TLBO algorithm. }\end{array}$ \\
\hline 34. & Pawar and Rao (2013a,b) & $\begin{array}{l}\text { TLBO algorithm was applied to optimize the process parameters of three } \\
\text { machining processes including an advanced machining process known as } \\
\text { abrasive water jet machining process and two important conventional } \\
\text { machining processes namely grinding and milling. }\end{array}$ \\
\hline 35. & Rao et al. (2013) & $\begin{array}{l}\text { An automatic medical image segmentation was attempted using TLBO } \\
\text { algorithm. }\end{array}$ \\
\hline 36. & Rao et al. (2013) & Scramjet inlet design was carried out using TLBO algorithm. \\
\hline 37. & Rao and Patel (2013a) & $\begin{array}{l}\text { The elitist TLBO algorithm was implemented on } 76 \text { unconstrained } \\
\text { optimization problems having different characteristics to identify the effect } \\
\text { of elitism and common controlling parameters. The results obtained by using } \\
\text { TLBO algorithm were compared with the other optimization algorithms } \\
\text { available in the literature such as GA, PSO, DE, ABC, CES, FES, ESLAT } \\
\text { and CMA-ES. }\end{array}$ \\
\hline 38. & Rao and Patel (2013b) & $\begin{array}{l}\text { Modified the basic TLBO algorithm by introducing the concept of number } \\
\text { of teachers and adaptive teaching factor. The presented modifications } \\
\text { speeded up the convergence rate of the basic TLBO algorithm. The modified } \\
\text { TLBO algorithm was applied successfully to the multiobjective optimization } \\
\text { of heat exchangers. }\end{array}$ \\
\hline 39. & Rao and Patel (2013c) & $\begin{array}{l}\text { The modified TLBO algorithm was applied successfully to the } \\
\text { multiobjective optimization of a two stage thermoelectric cooler (TEC) }\end{array}$ \\
\hline 40. & Rao and Patel (2013d) & $\begin{array}{l}\text { Performance of the improved TLBO algorithm was assessed by } \\
\text { implementing it on a range of standard unconstrained benchmark functions } \\
\text { having different characteristics. }\end{array}$ \\
\hline
\end{tabular}




\section{Table 13}

Research papers published in the year 2013 Continued

\begin{tabular}{|c|c|c|}
\hline S.No. & Authors & Work carried out \\
\hline 41. & $\begin{array}{l}\text { Rao and Kalyankar } \\
\text { (2013a) }\end{array}$ & $\begin{array}{l}\text { Carried out the parameter optimization of a multi-pass turning operation using the } \\
\text { TLBO algorithm. Two different examples were considered that were attempted } \\
\text { previously by various researchers using different optimization techniques, such as SA, } \\
\text { GA, ACO, PSO, etc. }\end{array}$ \\
\hline 42. & $\begin{array}{l}\text { Rao and Kalyankar } \\
\text { (2013b) }\end{array}$ & $\begin{array}{l}\text { Applied the TLBO algorithm for the process parameter optimization of selected } \\
\text { modern machining processes. }\end{array}$ \\
\hline 43. & $\begin{array}{l}\text { Rao and Waghmare } \\
\text { (2013) }\end{array}$ & Solved complex composite test functions using TLBO algorithm. \\
\hline 44. & Roy (2013) & $\begin{array}{l}\text { Applied a modified version of TLBO for solving the short term Hydro-Thermal } \\
\text { Scheduling problem considering valve point effect and prohibited discharge } \\
\text { constraint. }\end{array}$ \\
\hline 45. & Roy et al. (2013) & $\begin{array}{l}\text { Applied a modified version of TLBO for solving the short term Hydro-Thermal } \\
\text { Scheduling problem with highly complex and nonlinear relationship of the problem } \\
\text { variables }\end{array}$ \\
\hline 46. & Sahu et al. (2013) & The TLBO was implemented on classification using neural network in data mining. \\
\hline 47. & $\begin{array}{l}\text { Satapathy et al. } \\
\text { (2013a) }\end{array}$ & $\begin{array}{l}\text { Proposed an orthogonal design based TLBO (OTLBO) algorithm. The OTLBO } \\
\text { algorithm was incorporated with the orthogonal design and thus generated an optimal } \\
\text { offspring by a statistical optimal method. }\end{array}$ \\
\hline 48. & $\begin{array}{l}\text { Satapathy et al. } \\
\text { (2013b) }\end{array}$ & $\begin{array}{l}\text { The weighted TLBO (WTLBO) algorithm was tried on several benchmark } \\
\text { optimization problems. }\end{array}$ \\
\hline 49. & $\begin{array}{l}\text { Satapathy et al. } \\
\text { (2013c) }\end{array}$ & $\begin{array}{l}\text { TLBO clustering algorithm was applied to cluster the given information. Rough set } \\
\text { and TLBO algorithm were applied for selecting features. }\end{array}$ \\
\hline 50. & $\begin{array}{l}\text { Satapathy and Naik } \\
\text { (2013) }\end{array}$ & Presented Cooperative TLBO employing cooperative behavior. \\
\hline 51. & $\begin{array}{l}\text { Singh and Verma } \\
\text { (2013) }\end{array}$ & $\begin{array}{l}\text { Presented the TLBO algorithm to solve parameter identification problems in the } \\
\text { designing of a digital infinite impulse response (IIR) filter. }\end{array}$ \\
\hline 52. & Singh et al. (2013) & $\begin{array}{l}\text { Discussed the application of TLBO algorithm for optimal coordination of DOCR } \\
\text { relays in a looped power system. }\end{array}$ \\
\hline 53. & $\begin{array}{l}\text { Sreenivas et al. } \\
\text { (2013) }\end{array}$ & $\begin{array}{l}\text { An optimal design of coordinated PI based PSS with TCSC controller using modified } \\
\text { teaching learning based optimization was carried out. }\end{array}$ \\
\hline 54. & Tang et al. (2013) & $\begin{array}{l}\text { Proposed an improved TLBO algorithm with Memetic method (ITLBO-M). The } \\
\text { memetic method improved the global exploring ability whereas the one-to-one } \\
\text { teaching improved the local searchability. }\end{array}$ \\
\hline 55. & $\begin{array}{l}\text { Theja and } \\
\text { Rajasekhar (2013) }\end{array}$ & $\begin{array}{l}\text { Applied a modified version of TLBO algorithm for designing Proportional-Integral } \\
\text { (PI) controller based Power System Stabilizer (PSS). }\end{array}$ \\
\hline 56. & Toğan (2013) & Designed pin jointed structures using TLBO algorithm. \\
\hline 57. & Tuo et al. (2013) & $\begin{array}{l}\text { Proposed an Improved Harmony Search Based Teaching Learning (HSTL) } \\
\text { optimization algorithm in order to maintain a balance between the convergence speed } \\
\text { and the population diversity. }\end{array}$ \\
\hline 58. & Waghmare (2013) & $\begin{array}{l}\text { Made comments on a note published by Črepinšek et al. (2012) who tried to invalidate } \\
\text { the performance supremacy of the TLBO algorithm. The views and the experimental } \\
\text { results presented by Črepinšek et al. (2012) were re-examined and correct } \\
\text { understanding of the TLBO algorithm was presented in an objective manner. }\end{array}$ \\
\hline 59. & Wang et al. (2013) & $\begin{array}{l}\text { Surveyed the running mechanism of TLBO for dealing with the real-parameter } \\
\text { optimization problems and finally grouped its real world applications. }\end{array}$ \\
\hline 60. & Yildiz (2013) & $\begin{array}{l}\text { Integrated Taguchi method with the TLBO algorithm known as the Hybrid Robust } \\
\text { TLBO (HRTLBO) algorithm. }\end{array}$ \\
\hline 61. & Zou et al. (2013a) & Proposed a multi-swarm TLBO algorithm for optimization in dynamic environment. \\
\hline 62. & Zou et al. (2013b) & $\begin{array}{l}\text { Proposed a TLBO algorithm for multiobjective optimization problems (MOPs) by } \\
\text { adopting the nondominated sorting concept and the mechanism of crowding distance } \\
\text { computation. }\end{array}$ \\
\hline
\end{tabular}


Table 14

Research papers published in the year 2014

\begin{tabular}{|c|c|c|}
\hline S.No. & Authors & Work carried out \\
\hline 63. & Abirami et al. (2014) & $\begin{array}{l}\text { Presented the details of integrated maintenance scheduling for the secure } \\
\text { operation. The problem was formulated as a complex optimization } \\
\text { problem that affects the unit commitment and economic dispatch } \\
\text { schedules. }\end{array}$ \\
\hline 64. & Alneamy and Alnaish (2014) & $\begin{array}{l}\text { Heart disease diagnosis was carried out utilizing hybrid fuzzy wavelet } \\
\text { neural network and TLBO algorithm. }\end{array}$ \\
\hline 65. & Arya and Koshti (2014) & $\begin{array}{l}\text { Presented a load shedding algorithm for alleviating line overloads } \\
\text { employing the TLBO algorithm. }\end{array}$ \\
\hline 66. & Aydogdu and Akin (2014) & TLBO algorithm was used for optimum design of steel buildings. \\
\hline 67. & Baghlani (2014) & $\begin{array}{l}\text { Water level stabilization in open channels was attempted using Chebyshev } \\
\text { polynomials and TLBO algorithm. }\end{array}$ \\
\hline 68. & Baykasoğlu et al. (2014) & $\begin{array}{l}\text { Analyzed the performance of TLBO algorithm on combinatorial } \\
\text { optimization problems. The performance of the TLBO algorithm was } \\
\text { tested on some combinatorial optimization problems, namely flow shop } \\
\text { (FSSP) and job shop scheduling problems (JSSP). }\end{array}$ \\
\hline 69. & Bhattacharjee et al. (2014) & $\begin{array}{l}\text { TLBO was used to solve Economic Load Dispatch (ELD) problems } \\
\text { involving different linear and non-linear constraints. }\end{array}$ \\
\hline 70. & Bouchekara et al. (2014) & $\begin{array}{l}\text { Used TLBO algorithm to solve the optimal power flow problem. In order } \\
\text { to show the effectiveness of the method, it was applied to the standard } \\
\text { IEEE 30-bus and IEEE 118-bus test systems for different objectives that } \\
\text { reflect the performances of the power system. }\end{array}$ \\
\hline 71. & Camp and Farshchin (2014) & $\begin{array}{l}\text { Applied a modified TLBO algorithm to fixed geometry space trusses with } \\
\text { discrete and continuous design variables. }\end{array}$ \\
\hline 72. & Chandra and Sujiya (2014) & $\begin{array}{l}\text { Tamil speech recognition using hybrid technique of enhanced weighed } \\
\text { TLBO and HMM was carried out. }\end{array}$ \\
\hline 73. & Charak (2014) & $\begin{array}{l}\text { Optimal scheduling of multi-chain hydrothermal system using TLBO } \\
\text { algorithm was carried out. }\end{array}$ \\
\hline 74. & Chen et al. (2014) & $\begin{array}{l}\text { Proposed a modified TLBO algorithm for thinning and weighting planar } \\
\text { arrays to synthesize the desired antenna array factor. }\end{array}$ \\
\hline 75. & Cheng (2014) & Introduced TLBO algorithm to select the specific and feasible primers. \\
\hline 76. & Črepinšek et al. (2014) & $\begin{array}{l}\text { Tried to justify their previous work (Crepinšek et al., 2012) which was } \\
\text { commented upon by Waghmare et al. (2013). However, the justification } \\
\text { made by them is not convincing and many of the statements made by them } \\
\text { on the work of Waghmare (2013) are undesirable. }\end{array}$ \\
\hline 77. & Dede (2014) & $\begin{array}{l}\text { Considered several benchmark problems related to truss structures with } \\
\text { discrete design variables and showed the efficiency of the TLBO } \\
\text { algorithm and the results were compared with those reported in the } \\
\text { literature. }\end{array}$ \\
\hline 78. & Dib and Sharaqa (2014) & $\begin{array}{l}\text { Synthesis of thinned concentric circular antenna arrays was done using } \\
\text { TLBO algorithm. }\end{array}$ \\
\hline 79. & Dixit and Mishra (2014) & $\begin{array}{l}\text { Compared TLBO and Taguchi method by analyzing force in turning } \\
\text { operation. }\end{array}$ \\
\hline 80. & Ganesh and Reddy (2014) & $\begin{array}{l}\text { TLBO was used for economic dispatch problem with valve point loading } \\
\text { effect. }\end{array}$ \\
\hline 81. & Ganguly and Patel (2014) & $\begin{array}{l}\text { Used TLBO algorithm for the global minimization of a loss cost function } \\
\text { expressed as a function of three variables } n, h \text { and } k \text { in an economic model } \\
\text { of } X \text {-bar chart based on unified approach. }\end{array}$ \\
\hline 82. & Ghasemi et al. (2014) & $\begin{array}{l}\text { Applied a modified version of TLBO algorithm and Double Differential } \\
\text { Evolution (DDE) algorithm for solving Optimal Reactive Power Dispatch } \\
\text { (ORPD) problem. }\end{array}$ \\
\hline 83. & González-Álvarez et al. (2014) & $\begin{array}{l}\text { Proposed a multiobjective TLBO algorithm for solving the Motif } \\
\text { Discovery Problem (MDP). The results obtained using the TLBO } \\
\text { algorithm were compared with DEPT, MO-VNS, NSGA-II andSPEA2. }\end{array}$ \\
\hline 84. & Hoseini et al. (2014) & $\begin{array}{l}\text { Modified the teacher phase and the learner phase of the TLBO algorithm. } \\
\text { The modified TLBO algorithm was applied to determine the optimal } \\
\text { location of AVRs in the distribution system. }\end{array}$ \\
\hline
\end{tabular}




\section{Table 14}

Research papers published in the year 2014Continued

\begin{tabular}{|c|c|c|}
\hline S.No. & Authors & Work carried out \\
\hline 85. & Hwang et al. (2014) & TLBO algorithm was used with three biological properties for operon prediction: \\
\hline 86. & Jordehi (2014) & $\begin{array}{l}\text { Used TLBO algorithm to find the optimal setting of thyristor-controlled series } \\
\text { compensators in electric power systems. }\end{array}$ \\
\hline 87. & $\begin{array}{l}\text { Keesari and Rao } \\
\text { (2014) }\end{array}$ & $\begin{array}{l}\text { Used the TLBO algorithm to solve the job shop scheduling problems to minimize the } \\
\text { makespan. }\end{array}$ \\
\hline 88. & $\begin{array}{l}\text { Krishnasamy and } \\
\text { Nanjundappan } \\
\text { (2014) }\end{array}$ & $\begin{array}{l}\text { Integrated the TLBO algorithm with Sequential Quadratic Programming (SQP) to fine } \\
\text { tune the better solutions obtained by the TLBO algorithms. }\end{array}$ \\
\hline 89. & Lim and Isa (2014a) & $\begin{array}{l}\text { Proposed to integrate the PSO algorithm with the TLBO algorithm in order to offer an } \\
\text { alternative learning strategy in case a particle fails to improve its fitness. }\end{array}$ \\
\hline 90. & Lim and Isa (2014b) & $\begin{array}{l}\text { Proposed an improved TLBO algorithm adapted to the enhanced framework of PSO } \\
\text { known as Bidirectional Teaching and Peer Learning Particle Swarm Optimization } \\
\text { (BTPLPSO). }\end{array}$ \\
\hline 91. & Lin et al. (2014) & $\begin{array}{l}\text { Proposed a direct method to quantify the carbon emissions in turning operations. } \\
\text { Moreover, a multiobjective TLBO algorithm was proposed and two objectives of } \\
\text { minimizing the carbon emissions and the operation time were considered. }\end{array}$ \\
\hline 92. & Luo et al. (2014) & Synthesis of thinned square array was done using modified TLBO algorithm. \\
\hline 93. & $\begin{array}{l}\text { Mandal and Roy } \\
\text { (2014) }\end{array}$ & $\begin{array}{l}\text { Applied the Quasi Oppositional TLBO (QTLBO) algorithm to solve the multiobjective } \\
\text { power flow problem with multiple constraints. }\end{array}$ \\
\hline 94. & $\begin{array}{l}\text { Mardaneh and } \\
\text { Golstaneh (2014) }\end{array}$ & $\begin{array}{l}\text { Proposed a harmonic elimination technique for online reducing harmonics in voltage } \\
\text { source inverters. The modified version of the TLBO algorithm was successfully } \\
\text { implemented to achieve optimal switching angles. }\end{array}$ \\
\hline 95. & Medina et al. (2014) & $\begin{array}{l}\text { Used a multi-objective TLBO algorithm for reduction of power losses in a power test } \\
\text { system. }\end{array}$ \\
\hline 96. & $\begin{array}{l}\text { Moghadam and Seifi } \\
\text { (2014) }\end{array}$ & $\begin{array}{l}\text { Proposed a Fuzzy-TLBO algorithm to solve the Optimal Reactive Power Control } \\
\text { Variable Planning (ORPVCP) problem with an objective to minimize the energy loss. }\end{array}$ \\
\hline 97. & Murty et al. (2014) & Automatic clustering was attempted using TLBO algorithm. \\
\hline 98. & Patel et al. (2014) & $\begin{array}{l}\text { Proposed a simple, efficient and reliable method to extract all five parameters of a solar } \\
\text { cell from a single illuminated current-voltage characteristic using TLBO algorithm. }\end{array}$ \\
\hline 99. & Pholdee et al. (2014) & $\begin{array}{l}\text { Integrated the differential operators into the TLBO with a Latin hypercube sampling } \\
\text { technique for generation of an initial population in order to improve the flatness of a } \\
\text { strip during strip coiling process. }\end{array}$ \\
\hline 100. & $\begin{array}{l}\text { Ramoji and Kumar } \\
\text { (2014) }\end{array}$ & $\begin{array}{l}\text { Optimal economical sizing of a PV-wind hybrid energy system was done using genetic } \\
\text { algorithm and TLBO algorithm. }\end{array}$ \\
\hline 101. & $\begin{array}{l}\text { Rao and Kalyankar } \\
\text { (2014) }\end{array}$ & Applied TLBO algorithm for optimization of abrasive flow machining process. \\
\hline 102. & Rao and More (2014) & $\begin{array}{l}\text { Used TLBO algorithm for optimal selection of design and manufacturing tolerances } \\
\text { with an alternative manufacturing process to obtain the optimal solution nearer to the } \\
\text { global optimal solution. The comparison of the proposed algorithm was made with the } \\
\text { GA, NSGA-II, and MOPSO. }\end{array}$ \\
\hline 103. & Rao et al. (2014) & $\begin{array}{l}\text { Considered the mathematical models of three important casting processes namely } \\
\text { squeeze casting, continuous casting and die casting for the parameter optimization of } \\
\text { respective processes. The TLBO algorithm was used for the parameters optimization } \\
\text { of these casting processes. }\end{array}$ \\
\hline 104. & Rao and Patel (2014) & $\begin{array}{l}\text { Proposed a multiobjective improved TLBO algorithm for unconstrained and } \\
\text { constrained multiobjective function optimization. The algorithm used a grid-based } \\
\text { approach to adaptively assess the non-dominated solutions maintained in an external } \\
\text { archive. The performance of the algorithm was assessed by implementing it on the } \\
\text { unconstrained and constrained test problems of CEC } 2009 \text { competition. }\end{array}$ \\
\hline 105. & $\begin{array}{l}\text { Rao and Waghmare } \\
\text { (2014a) }\end{array}$ & $\begin{array}{l}\text { Solved the same problems of CEC } 2009 \text { using simple TLBO algorithm and produced } \\
\text { better results. The results were compared with other algorithms such as AMGA, } \\
\text { Clustering MOEA, DECMOSA-SQP, DMOEADD, GDE3, LiuLi Algorithm, } \\
\text { MOEAD, MOEADGM, etc. }\end{array}$ \\
\hline 106. & $\begin{array}{l}\text { Rao and Waghmare } \\
\text { (2014b) }\end{array}$ & $\begin{array}{l}\text { Thermoeconomic optimization of a shell and tube condenser was carried out using } \\
\text { TLBO algorithm. }\end{array}$ \\
\hline
\end{tabular}


Table 14

Research papers published in the year 2014 Continued

\begin{tabular}{|c|c|c|}
\hline S.No. & Authors & Work carried out \\
\hline 107. & Roy and Bhui (2014) & $\begin{array}{l}\text { Applied QTLBO algorithm for solving the nonlinear multiobjective economic emission } \\
\text { load dispatch problem of electric power generation with valve point loading. }\end{array}$ \\
\hline 108. & $\begin{array}{l}\text { Roy and Sarkar } \\
(2014)\end{array}$ & $\begin{array}{l}\text { Applied QTLBO to solve the unit commitment problem. The test results obtained were } \\
\text { compared with those obtained using other algorithms such as Evolutionary Programming } \\
\text { (EP), GA, Gravity Search Algorithm (GSA), IPSO, IQEA-UC, PSO, SA, QEA-UC and } \\
\text { basic TLBO algorithms. }\end{array}$ \\
\hline 109. & Roy et al. (2014) & $\begin{array}{l}\text { Incorporated oppositional based learning in the basic TLBO algorithm. The oppositional } \\
\text { TLBO algorithm was applied to solve the combined heat and power dispatch problem } \\
\text { with bounded feasible operating region. }\end{array}$ \\
\hline 110. & Sahoo et al. (2014) & TLBO algorithm was used for character recognition. \\
\hline 111. & $\begin{array}{l}\text { Satapathy and Naik } \\
\text { (2014) }\end{array}$ & $\begin{array}{l}\text { Investigated the performance of a new variant of TLBO for global function optimization } \\
\text { problems. Several advanced variants of PSO, DE and ABC were considered for the } \\
\text { comparison purpose. CEC } 2005 \text { suite of benchmark functions were chosen on real } \\
\text { parameter optimization. }\end{array}$ \\
\hline 112. & $\begin{array}{l}\text { Shabanpour- } \\
\text { Haghighi et al. } \\
\text { (2014) }\end{array}$ & $\begin{array}{l}\text { Proposed a modified TLBO algorithm with self adaptive wavelet mutation strategy and } \\
\text { fuzzy clustering technique to control the size of the repository and smart population } \\
\text { selection for the next iteration. }\end{array}$ \\
\hline 113. & $\begin{array}{ll}\text { Siripuram and } \\
\text { Kumar (2014) }\end{array}$ & Optimal sizing and location of distributed generation using improved TLBO algorithm. \\
\hline 114. & $\begin{array}{l}\text { Sreenivasulu et al. } \\
\text { (2014) }\end{array}$ & Generation of alternative process plans was done using TLBO algorithm. \\
\hline 115. & $\begin{array}{l}\text { Sultana and Roy } \\
\text { (2014) }\end{array}$ & $\begin{array}{l}\text { Applied multiobjective QTLBO algorithm for optimal location of distributed generator } \\
\text { in the radial distribution system. }\end{array}$ \\
\hline 116. & $\begin{array}{l}\text { Tuncel and Aydin } \\
\text { (2014) }\end{array}$ & $\begin{array}{l}\text { The TLBO algorithm was employed to solve the line balancing problem and the } \\
\text { computational results were compared in terms of the line efficiency. }\end{array}$ \\
\hline 117. & Uzlu et al. (2014a) & $\begin{array}{l}\text { Performed experimental studies in a wave flume with regular waves. TLBO and ABC } \\
\text { algorithms were applied to regression functions of the data. }\end{array}$ \\
\hline 118. & Uzlu et al. (2014b) & $\begin{array}{l}\text { Applied the ANN (artificial neural network) model with the TLBO algorithm to estimate } \\
\text { energy consumption in Turkey. }\end{array}$ \\
\hline 119. & Wang et al. (2014a) & $\begin{array}{l}\text { Proposed a hybrid TLBO-DE algorithm for chaotic time series prediction. To } \\
\text { demonstrate the effectiveness of TLBO-DE approach, it was applied to three typical } \\
\text { chaotic nonlinear time series prediction problems. }\end{array}$ \\
\hline 120. & Wang et al. (2014b) & $\begin{array}{l}\text { Introduced a ring neighborhood topology into the original TLBO algorithm to maintain } \\
\text { the exploration ability of the population. }\end{array}$ \\
\hline 121. & Xiao et al. (2014) & $\begin{array}{l}\text { A multiobjective optimization problem was formulated and a modified TLBO algorithm } \\
\text { was used to coordinate the Thyristor Controlled Series Capacitor (TCSC), Static } \\
\text { Var Compensator (SVC) and power angle difference damping characteristics. }\end{array}$ \\
\hline 122. & Xia et al. (2014) & $\begin{array}{l}\text { Disassembly Sequence Planning (DSP) is a challenging NP-hard combinatorial } \\
\text { optimization problem. A Simplified Teaching-Learning-Based Optimization (STLBO) } \\
\text { algorithm for solving DSP problems is presented. }\end{array}$ \\
\hline 123. & Xie et al. (2014) & $\begin{array}{l}\text { Described the general knowledge of the teacher-student relationships and the } \\
\text { fundamentals and performance of TLBO algorithm. }\end{array}$ \\
\hline 124. & Xing and Gao (2014) & $\begin{array}{l}\text { Proposed a hybrid TLBO which combines the TLBO algorithm for solution evolution } \\
\text { and a variable neighborhood search (VNS) for fast solution improvement for Permutation } \\
\text { flow shop scheduling. }\end{array}$ \\
\hline 125. & Yang et al. (2014a) & $\begin{array}{l}\text { Proposed a new compact TLBO algorithm to combine the strength of the original TLBO } \\
\text { and to reduce the memory requirement through a compact structure that utilized an } \\
\text { adaptive statistic description to replace the process of a population of solutions. }\end{array}$ \\
\hline 126. & Yang et al. (2014b) & $\begin{array}{l}\text { A self-learning TLBO was used for dynamic economic/environmental dispatch } \\
\text { considering multiple plug-in electric vehicle loads. }\end{array}$ \\
\hline 127. & Yu et al. (2014a) & $\begin{array}{l}\text { Proposed a modified version of TLBO algorithm in which a feedback phase, mutation } \\
\text { crossover operation of differential evolution (DE) algorithms, and chaotic perturbation } \\
\text { mechanism were incorporated to improve the performance. }\end{array}$ \\
\hline 128. & Yu et al. (2014b) & Unmanned aerial vehicle path planning based on TLBO algorithm was carried out. \\
\hline 129. & Zhang et al. (2014) & Optimal approximation of linear systems was done using TLBO algorithm. \\
\hline 130. & Zou et al. (2014a) & $\begin{array}{l}\text { Proposed a modified TLBO algorithm with Dynamic Group Strategy. Experiments were } \\
\text { conducted on } 18 \text { benchmark functions with } 50 \text { dimensions. }\end{array}$ \\
\hline 131. & Zou et al. (2014b) & $\begin{array}{l}\text { A new TLBO variant called bare-bones teaching-learning-based optimization was } \\
\text { presented to solve the global optimization problems. }\end{array}$ \\
\hline
\end{tabular}




\section{Table 15}

Research papers published in the year 2015

\begin{tabular}{|c|c|c|}
\hline S.No. & Authors & Work carried out \\
\hline 132. & Agrawal et al. (2015) & $\begin{array}{l}\text { Proposed TLBO algorithm based iris recognition system in which feature extraction } \\
\text { phase of iris recognition system was optimized by using TLBO algorithm. }\end{array}$ \\
\hline 133. & $\begin{array}{l}\text { Akin and Aydogdu } \\
(2015)\end{array}$ & $\begin{array}{l}\text { Optimum design of steel space frames by hybrid TLBO and harmony search } \\
\text { algorithms was carried out. }\end{array}$ \\
\hline 134. & $\begin{array}{l}\text { Babu and Palaniswamy } \\
\text { (2015) }\end{array}$ & $\begin{array}{l}\text { Formulated a new DC link placement problem through extending the standard OPF to } \\
\text { embrace DC link equations and presented TLBO algorithm for solving the problem. }\end{array}$ \\
\hline 135. & Banerjee et al. (2015) & $\begin{array}{l}\text { Used TLBO algorithm for economic load dispatch problem considering valve point } \\
\text { loading effect. }\end{array}$ \\
\hline 136. & Barisal (2015) & $\begin{array}{l}\text { Presented TLBO algorithm and its application to automatic load frequency control of } \\
\text { multi-source power system having thermal, hydro and gas power plants. }\end{array}$ \\
\hline 137. & $\begin{array}{l}\text { Bayat and Delavari } \\
(2015)\end{array}$ & $\begin{array}{l}\text { Performance evaluation of power system stabilizers of a multi-machine system was } \\
\text { carried out using TLBO algorithm. }\end{array}$ \\
\hline 138. & Bayram et al. (2015) & Modeled stream dissolved oxygen concentration using TLBO algorithm. \\
\hline 139. & $\begin{array}{l}\text { Boudjefdjouf et al. } \\
\text { (2015) }\end{array}$ & $\begin{array}{l}\text { Combined the time-domain reflectometry response extracted from vector network } \\
\text { analyzer measurements and the TLBO technique and applied to the diagnosis of } \\
\text { wiring networks. }\end{array}$ \\
\hline 140. & Cao and Luo (2015) & $\begin{array}{l}\text { A study on SVM based on the weighted elitist TLBO was carried out and applied in } \\
\text { the fault diagnosis of a chemical process. }\end{array}$ \\
\hline 141. & $\begin{array}{l}\text { Chakravarthy et al. } \\
\text { (2015) }\end{array}$ & Non-uniform circular array synthesis was carried out using TLBO algorithm. \\
\hline 142. & $\begin{array}{l}\text { Chaves-González et al. } \\
\text { (2015) }\end{array}$ & $\begin{array}{l}\text { TLBO algorithm with Pareto tournament was used for the multiobjective software } \\
\text { requirements selection. }\end{array}$ \\
\hline 143. & Chen et al. (2015a) & $\begin{array}{l}\text { In order to decrease the computation cost and improve the global performance of the } \\
\text { original TLBO algorithm, the area copying operator of the producer-scrounger (PS) } \\
\text { model was introduced into TLBO for global optimization problems. }\end{array}$ \\
\hline 144. & Chen et al. (2015b) & $\begin{array}{l}\text { Proposed a variant of TLBO algorithm with multi-classes cooperation and simulated } \\
\text { annealing operator (SAMCCTLBO). }\end{array}$ \\
\hline 145. & Chen et al. (2015c) & $\begin{array}{l}\text { A novel selective ensemble classification of microarray data was done based on TLBO } \\
\text { algorithm. }\end{array}$ \\
\hline 146. & Chen et al. (2015d) & $\begin{array}{l}\text { Variable population size TLBO algorithm was proposed and applied to ANN and } \\
\text { global optimization. }\end{array}$ \\
\hline 147. & Chen et al. (2015e) & Proposed an improved TLBO algorithm for solving global optimization problems. \\
\hline 148. & Cheng (2015a) & $\begin{array}{l}\text { Estimation of TLBO primer design using regression analysis for different melting } \\
\text { temperature calculations was carried out. }\end{array}$ \\
\hline 149. & Cheng (2015b) & $\begin{array}{l}\text { A novel TLBO algorithm was proposed for improved mutagenic primer design in } \\
\text { mismatch PCR-RFLP SNP genotyping. }\end{array}$ \\
\hline 150. & Cho and Kim (2015) & $\begin{array}{l}\text { Introduced a new design method using a hybrid optimization algorithm for the } \\
\text { electromagnet used in maglev transportation vehicles. }\end{array}$ \\
\hline 151. & Črawford et al. (2015) & $\begin{array}{l}\text { Applied TOBO algorithm for solving } 65 \text { benchmark set covering problems of } \\
\text { combinatorial nature. }\end{array}$ \\
\hline 152. & Das and Padhy (2015) & $\begin{array}{l}\text { Forecasted a financial derivatives instrument (the commodity futures contract index) } \\
\text { using techniques based on machine learning techniques. The authors had developed a } \\
\text { hybrid method that combined a support vector machine (SVM) with TLBO algorithm. }\end{array}$ \\
\hline 153. & Dede and Ayvaz (2015) & Used TLBO algorithm for the size and shape optimization of structures. \\
\hline 154. & Dokeroglu (2015) & $\begin{array}{l}\text { Proposed a set of TLBO-based hybrid algorithms to solve the challenging } \\
\text { combinatorial optimization problem of quadratic assignment. }\end{array}$ \\
\hline 155. & Durai et al. (2015) & $\begin{array}{l}\text { Provided a framework using TLBO algorithm for the computation of coefficients for } \\
\text { quadratic and cubic cost functions, valve point loading, piece-wise quadratic cost and } \\
\text { emission functions. }\end{array}$ \\
\hline 156. & Dwivedi et al. (2015) & Proposed TLBO algorithm for antenna designing. \\
\hline 157. & Ghasemi et al. (2015) & $\begin{array}{l}\text { Proposed a novel hybrid algorithm of imperialist competitive algorithm and teaching } \\
\text { learning algorithm for optimal power flow problem with non-smooth cost functions. }\end{array}$ \\
\hline 158. & $\begin{array}{l}\text { Govardhan and Roy } \\
\text { (2015) }\end{array}$ & $\begin{array}{l}\text { The TLBO algorithm was employed to solve the unit commitment problem } \\
\text { considering IEEE standard } 10 \text { unit test system }\end{array}$ \\
\hline 159. & Huang et al. (2015a) & $\begin{array}{l}\text { Proposed a new hybrid algorithm named teaching-learning-based cuckoo search } \\
\text { (TLCS) for the constrained optimization problems. }\end{array}$ \\
\hline 160. & Huang et al. (2015b) & $\begin{array}{l}\text { Proposed a new hybrid algorithm named teaching-learning-based cuckoo search } \\
\text { (TLCS) for the parameter optimization in structure designing and machining. }\end{array}$ \\
\hline
\end{tabular}


Table 15

Research papers published in the year 2015 Continued

\begin{tabular}{lll}
\hline S.No. & \multicolumn{1}{c}{ Authors } & \multicolumn{1}{c}{ Work carried out } \\
\hline 161. & $\begin{array}{l}\text { Hosseinpour } \\
\text { and Bastaee (2015) }\end{array}$ & $\begin{array}{l}\text { Presented a multiobjective optimal location of on-load tap changers (OLTCs) in } \\
\text { distribution systems at spirit of distributed generators (DGs) based on TLBO coupled } \\
\text { with SA algorithm (SA-TLBO). }\end{array}$ \\
162. & $\begin{array}{l}\text { Kadambur } \\
\text { Kotecha (2015) }\end{array}$ & $\begin{array}{l}\text { Proposed an alternate elitist TLBO algorithm based strategy to production planning } \\
\text { problem of a petrochemical industry. } \\
\text { presented an improved variant of TLBO algorithm to deal with the problem of } \\
\text { simultaneous allocation of the distributed resources in radial distribution networks while } \\
\text { considering multi-level load scenario. }\end{array}$ \\
164. Kanwar et al. (2015) & Kumar et al. (2015) & $\begin{array}{l}\text { Utilized TLBO algorithm in order to determine the optimal maching conditions for } \\
\text { achieving satisfactory machining performances. The application potential of TLBO } \\
\text { algorithm was compared to that of GA. }\end{array}$
\end{tabular}

165. Kumar and Samuel Described TLBO algorithm for the optimization of mechanical design problems..

(2015)

166. Kurada et al. (2015) Persuaded a novel automatic clustering algorithm (AutoTLBO) with a credible prospect by coalescing automatic assignment of $k$ value in partitioned clustering algorithms and cluster validations into TLBO.

167. Lahari et al. (2015) Partition based clustering using GA and TLBO algorithms was carried out.

168. Li et al. (2015) Proposed a discrete TLBO (DTLBO) for solving the flowshop rescheduling problem.

169. Lin et al. (2015) Used mutiobjective TLBO algorithm for scheduling in turning processes to minimize the makespan and carbon footprint.

170. Mukhopadhyay et al. Presented a secured optimal power flow solution by integrating Thyristor controlled (2015) series compensator (TCSC) with the optimization model developed under overload condition and TLBO algorithm was used.

171. Niknam et al. (2015) A new TLBO algorithm incorporated with mutation was developed for distribution system state estimation.

172. Omidvar et al. (2015) A radial basis function neural network (RBFNN) was developed and used as an objective function for maximizing deformation through TLBO algorithm.

173. Ouyang et al. (2015) TLBO algorithm with global crossover for global optimization was proposed.

174. Rajaram et al. (2015) Airfoil topology optimization was carried out using TLBO algorithm.

175. Rao (2015) Described the TLBO, elitist TLBO (ETLBO) and non-dominated sorting TLBO (NSTLBO) algorithms and their engineering applications.

176. Rao and More (2015) Carried out single objective as well as multiobjective design optimization of heat pipe using TLBO algorithm. The results were compared with the NPGA (Niched Pareto Genetic Algorithm), GEM (Grenade Explosion Method) and GEO (Generalized External optimization).

177. Rao and Rai (2015a) Applied TLBO and NSTLBO algorithms for the optimization of parameters of fused deposition modeling process.

178. Rao and Rai (2015b) Applied TLBO algorithm for optimization of advanced fnishing processes.

179. Rao and Waghmare Presented the performance of (TLBO) algorithm to obtain the optimum geometrical (2015a) dimensions of a robot gripper. Five objectives, namely the difference between the maximum and minimum gripping forces, the force transmission ratio, the shift transmission ratio, length of all the elements of the gripper, and the effort of the gripper mechanism were considered as objective functions. Three robot grippers were optimized.

180. Rao and Waghmare Presented the performance of the TLBO algorithm to obtain the optimum set of design (2015b) and operating parameters for a smooth flat plate solar air heater (SFPSAH). Maximization of thermal efficiency was considered as an objective function for the thermal performance of SFPSAH.

181. Rao and Waghmare Investigated the performance of the TLBO algorithm for multiobjective design (2015c) optimization of a plate fin heat sink equipped with flow-through and impingement-flow air cooling system. Two objective functions known as entropy generation rate and material cost with five constraints were used to measure the performance of the heat sink. Number of fins, height of fins, spacing between two fins and oncoming air velocity were considered as the design variables.

182. Recioui et al. (2015) Proposed binary TLBO algorithm to the optimal placement of phasor measurement units.

183. Roy et al. (2015) The results of the TLBO optimized PID controllers on a two area reheat thermal system were compared with those of ABC and DE optimized PID controllers.

184. Samet et al. (2015) A modified TLBO algorithm was developed for the location and size of two SVCs to compensate the railway's voltage drop. 


\section{Table 15}

Research papers published in the year 2015Continued

\begin{tabular}{|c|c|c|}
\hline S.No. & Authors & Work carried out \\
\hline 185. & Sandeep et al. (2015) & $\begin{array}{l}\text { General Purpose Graphic Processing Unit (GPGPU) based implementation of TLBO } \\
\text { and ABC algorithms was discussed to solve the unconstrained benchmark problems. }\end{array}$ \\
\hline 186. & Sahu et al. (2015a) & $\begin{array}{l}\text { The TLBO algorithm was applied to obtain the parameters of the fuzzy-PID } \\
\text { controller. }\end{array}$ \\
\hline 187. & Sahu et al. (2015b) & $\begin{array}{l}\text { Presented the design and analysis of Proportional-Integral-Double Derivative (PIDD) } \\
\text { controller for Automatic Generation Control (AGC) of multi-area power systems } \\
\text { with diverse energy sources using TLBO algorithm. }\end{array}$ \\
\hline 188. & $\begin{array}{l}\text { Satapathy and Naik } \\
\text { (2015) }\end{array}$ & A modified TLBO algorithm (mTLBO) was proposed for global search. \\
\hline 189. & $\begin{array}{l}\text { Sayare and Kamble } \\
\text { (2015) }\end{array}$ & $\begin{array}{l}\text { Parameter optimization of composite leaf spring using TLBO algorithm was carried } \\
\text { out. }\end{array}$ \\
\hline 190. & Sharma et al. (2015) & $\begin{array}{l}\text { Performance comparison of TLBO and PSO algorithms was carried out while } \\
\text { designing an adaptive channel equalizer. }\end{array}$ \\
\hline 191. & $\begin{array}{l}\text { Singh and Dhillon } \\
(2015)\end{array}$ & Designed an optimal IIR digital filter using TLBO algorithm. \\
\hline 192. & $\begin{array}{l}\text { Subramanian et al. } \\
(2015)\end{array}$ & $\begin{array}{l}\text { Reliable/cost-effective maintenance schedules for a composite power system using } \\
\text { fuzzy supported TLBO algorithm was attempted. }\end{array}$ \\
\hline 193. & Tiwary et al. (2015) & $\begin{array}{l}\text { Described a technique for optimizing inspection and repair based availability of } \\
\text { distribution systems. The TLBO algorithm was used for availability optimization. }\end{array}$ \\
\hline 194. & Turgut et al. (2015) & $\begin{array}{l}\text { TLBO was hybridized with Differential Evolution algorithm for successful } \\
\text { estimation of unknown proton exchange membrane fuel cell (PEMFC) model } \\
\text { parameters. }\end{array}$ \\
\hline 195. & $\begin{array}{l}\text { Umbarkar et al. } \\
(2015)\end{array}$ & Applied openMP TLBO algorithm over multi-core system \\
\hline 196. & Xu et al. (2015) & $\begin{array}{l}\text { Proposed an effective TLBO algorithm to solve the flexible job shop scheduling } \\
\text { problem. The results obtained by using TLBO algorithm were compared to those } \\
\text { obtained by using EDA, ABC, CGA, DIGA, PEGA, and PSO+SA algorithms. }\end{array}$ \\
\hline 197. & Yu et al. (2015) & $\begin{array}{l}\text { A self-adaptive multi-objective TLBO (SA-MTLBO) was proposed. In SA-MTLBO, } \\
\text { the learners can self-adaptively select the modes of learning according to their levels } \\
\text { of knowledge in classroom. }\end{array}$ \\
\hline 198. & Zhang et al. (2015a) & $\begin{array}{l}\text { An integrated approach for real-time model-based state of charge (SOC) estimation } \\
\text { of Lithium-ion batteries was proposed. An auto-regression model was adopted and } \\
\text { optimized off-line using a hybrid optimization method that combined the TLBO } \\
\text { method and the least square method. }\end{array}$ \\
\hline 199. & Zhang et al. (2015b) & $\begin{array}{l}\text { A hybrid bird mating optimizer algorithm with TLBO for global numerical } \\
\text { optimization was proposed. }\end{array}$ \\
\hline 200. & Zou et al. (2015) & $\begin{array}{l}\text { An improved TLBO algorithm (LETLBO) with learning experience of other learners } \\
\text { was proposed. }\end{array}$ \\
\hline
\end{tabular}

\section{Discussion}

It can be observed from the review of applications of TLBO algorithm that the algorithm has been successfully applied by various researchers in different fields of electrical engineering, mechanical design, thermal engineering, manufacturing engineering, civil engineering, structural engineering, computer engineering, electronics engineering, physics, chemistry, biotechnology, economics, etc. The number of applications of basic and modified versions of TLBO algorithm is increasing at a faster rate and it clearly proves the potential of the TLBO algorithm.

Rao et al. (2011, 2012a) showed that TLBO requires a fewer number of function evaluations as compared to the other optimization algorithms. Even though certain experiments were not conducted by Rao et al. (2011, 2012a) in the same settings, but a comparatively less number of function evaluations were chosen by them and proved the better performance of the TLBO algorithm. It was interesting to note that theother researchers themselves had used different numbers of function evaluations for the benchmark functions considered. The stopping conditions used by Rao et al. (2011, 2012a) in certain benchmark functions (with 30 runs each time) were better than those used by other 
researchers. Also, the TLBO algorithm showed better performance with less computational effort for the large scale problems, i.e. problems with high dimensions. However, in general, to maintain the consistency in comparison of algorithms, the number of function evaluations is to be maintained same for all the optimization algorithms including the TLBO algorithm for all the benchmark functions considered. Also, it may be mentioned here that, in general, the algorithm which requires fewer number of function evaluations to get the same best solution may be considered as a better algorithm compared to the other algorithms. If an algorithm gives global optimum solution within certain number of function evaluations, then consideration of more number of function evaluations may go on giving the same result.

Rao and Patel (2012) introduced the concept of elitism in the TLBO algorithm and investigated its effecton the performance of the algorithm for the constrained optimization problems. Moreover, the effect of common controlling parameters (i.e. population size, elite size and number of generations) on the performance of TLBO algorithm was also investigated by considering different combinations of common controlling parameters. The algorithm was implemented on 35 well defined constrained optimization problems having different characteristics to identify the effect of elitism and common controlling parameters. The results obtained by using TLBO algorithm were compared with the other optimization algorithms available in the literature such as PSO, DE, ABC, EP, etc. for the benchmark problems considered. Results had shown the satisfactory performance of TLBO algorithm for the constrained optimization problems. The computational experiments were conducted for the same number of function evaluations used by the other algorithms.

At this point, it is important to clarify that in the TLBO algorithm, the solution is updated in the teacher phase as well as in the learner phase. Hence, the total number of function evaluations in the TLBO algorithm can be computed as $(2 \times$ population size $\times$ number of generations). Rao and Patel (2012) computed the total number of function evaluations in the TLBO algorithm as $=\{(2 \times$ population size $\times$ number of generations) + (function evaluations required for duplicate elimination) $\}$ and they had used this formula to count the number of function evaluations while conducting experiments with TLBO algorithm. Since the 'function evaluations required for duplication removal' were not clearly known, Rao and Patel (2012) had reasonably approximated the same for different population sizes. The statement of Črepinšek et al. (2014) and their co-authors like Mernik et al. (2015) on approximating the 'function evaluations required for the duplication removal' seems to be biased and unjustified. In general, the researchers who have used the advanced optimization algorithms like GA, SA, ACO, PSO, DE, ABC, SFL, GSA, BBO, ES, NSGA, NSGA-II, VEGA, SPEA, etc. have hardly talked about the 'function evaluations required for the duplication removal' while using those algorithms for solving different optimization problems. The concept of 'function evaluations required for the duplication removal' was not even used by the previous researchers while comparing the performance of different algorithms on various benchmark functions. In fact, there may not be any such need in actual practice and it is not so meaningful.In fact, even though Mernik et al. (2015) described certain misconceptions when comparing different variants of the ABC algorithm, they had not shown computation of any 'function evaluations required for duplication removal' in ABC algorithm and its variants!

The total number of function evaluations in the TLBO algorithm can be simply computed as $(2 \times$ population size $\times$ number of generations). The factor " 2 " is used in the computation because the solution is updated in the teacher phase as well as in the learner phase of the TLBO algorithm. It may be mentioned here that, in general, when extra searches are not present in the algorithm, the total number of function evaluations required by many of the widely used optimization algorithms is computed by the researchers as (population size $\times$ number of generations). No separate provision was made in any of the widely used algorithms for computing the function evaluations required for the duplication removal and hence in TLBO also it may not be considered and it may not be required at all in actual practice. A statement made by Črepinšek et al. (2014) that "Waghmare is trying to justify that there is no need to explain all the steps of an algorithm using some other examples..................disagree with Waghmare's explanation that this is acceptable behavior...”" is incorrect as Waghmare (2013) had not 
made such comments. Also, the concept of calculation of function evaluations required for duplicate removal is quite unusual and one will not come across such concept in the widely accepted algorithms like GA, SA, ACO, PSO, DE, ABC, SFL, GSA, BBO, ES, NSGA, NSGA-II, VEGA, SPEA, etc. Hence, it is not a big point to discuss about in actual practice and probably no more redundant discussion is needed in this regard. Unnecessary (over)emphasis on 'function evaluations required for the duplication removal' is not required.

Črepinšek et al. (2014) tried to justify their previous work (Črepinšek et al., 2012) which was commented upon by Waghmare et al. (2013). However, the justification made by them is not convincing and many of the statements made by them on the work of Waghmare (2013) are questionable. There was no such inexact replication of computational experiments by Waghmare (2013) and certain comments made by Crepinšek et al. (2014) on the wisdom of the reviewers of Waghmare's paper are uncalled for. The authors had incorrectly opined that there was insufficient evidence that TLBO is better than the other nature-inspired algorithms on large-scale problems. However, Waghmare (2013) had already proved the better performance of the algorithm for optimization problems with 100 dimensions. It was not only Waghmare (2013) but researchers like Rao and Patel (2012, 2013a), Biswas et al. (2012), Satapathy et al. (2013a,b), Satapathy and Naik (2012,2013,2014), Zou et al. (2013b, 2014a) and many others had already proved that the TLBO algorithm is suitable for high dimensional problems and NP-hard combinatorial problems (Baykasoğlu et al., 2014; Črawford et al., 2015; Dokeroglu, 2015; Xia et al., 2014). Waghmare (2013) showed that TLBO algorithm can perform well on low dimensional problems also by properly tuning the common control parameters of the algorithm. Thus, the opinion of Črepinšek et al. (2015) on this aspect is incorrect. Furthermore, it may be noted that the paper of Rao and Patel (2012) was published on $15^{\text {th }}$ March 2012 whereas the paper of Črepinšek et al. (2012) was published on $28^{\text {th }}$ May 2012. It was not the responsibility of Rao and Patel (2012) if someone had not read the paper which was (and is) freely downloadable since $15^{\text {th }}$ March 2012 from the journal's website. There is no scope for any doubt in this regard.

Furthermore, Črepinšek et al. (2014) had mentioned about few "true” parameter-less algorithms and claimed that TLBO is not a parameter-less algorithm. But it should be realized that the so called algorithms mentioned by Črepinšek et al. (2014) also require values of parameters (for example, parameter-less GA of Harik and Lobo (1999) requires fixing the crossover probability of 0.5 and selection operator of 4 and runs multiple populations in a cascade-like manner; the PLES proposed by Papa (2008) and Papa et al. (2012) requires the parameters to set virtually, according to the complexity of the problem and according to the statistical properties of the solutions found). Hence, it does not mean that the "true" parameter-less algorithms as mentioned by Črepinšek et al. (2014) do not require the parameters.

The TLBO algorithm has never claimed that it is a parameter-less algorithm. What it has claimed is that it requires only the common parameters (like population size and number of generations) to tune and it does not require algorithm-specific parameters unlike the other algorithms. The common control parameters are required by all the algorithms and no algorithm is exceptional in this issue (and how the parameters are tuned is another issue). Few researchers have already started using self-adaptive common control parameters in TLBO algorithm. Črepinšek et al. (2014) stated that treating the control parameters as algorithm-specific parameters and common parameters as 'unusual' and commented that the TLBO algorithm is not a parameter-less algorithm. But it is not true and in fact their concept of " 'function evaluations required for the duplication removal' is very much unusual and it was not at all considered by the researchers who had developed and who had used the advanced optimization algorithms. Another statement made by Črepinšek et al. (2014) that "Instead of setting an algorithmspecific control parameter - the probability of mutation/crossover, the same effect is obtained in Waghmare (2013) by properly setting 'common' parameters-population size and number of generations..................instead of setting one 'algorithm-specific' control parameter, it is necessary to 
set two 'common' control parameters” is totally incorrect. It is to be understood by Črepinšek et al. (2014) that the GA algorithm requires algorithm-specific parameter(s) in addition to the common parameters and TLBO requires only the common parameters. More details about the TLBO algorithm can be obtained from https://sites.google.com/site/tlborao/.

\section{Conclusions}

The TLBO algorithm has carved a niche for itself in the field of advanced optimization and many researchers have understood the potential of the algorithm. The algorithm-specific parameter-less concept of the algorithm is one of the attracting features of the algorithm in addition to its simplicity and the ability to provide the global or near global optimum solutions in comparatively less number of function evaluations. Few researchers have made modifications to the basic TLBO algorithm and proved the effectiveness of the modified versions. However, to make the implementation of TLBO algorithm simpler, it is desirable to maintain the algorithm-specific parameter-less concept in the modified versions also. Otherwise, the user will be faced with the burden of tuning the algorithmspecific parameters in addition to the common control parameters.

The TLBO algorithm has never claimed that it is the 'best' algorithm among all the optimization algorithms available in the literature. In fact, there may not be any such 'best' algorithm existing! The TLBO algorithm is relatively a new algorithm and has strong potential to solve the optimization problems. If the algorithm is found having certain limitations then the efforts of the researchers should be to find the ways to overcome the limitations and to further strengthen the algorithm. The efforts should not be in the form of destructive criticism. What can be said with more confidence at present about the TLBO algorithm is that it is simple to apply, it has no algorithm-specific parameters and it provides the optimum results in a comparatively less number of function evaluations. There is no need to have any doubts on these aspects, as the algorithm has established itself and has set itself distinct. Researchers are encouraged to make improvements to the TLBO algorithm so that the algorithm will become much more powerful with much improved performance. It is hoped that the researchers belonging to different disciplines of engineering and sciences (physical, life and social) will find the TLBO algorithm as a powerful tool to optimize the systems and processes.

\section{Acknowledgement}

The author would like to thank the anonymous referees for constructive comments on the earlier version of this paper.

\section{References}

Abirami, M.,Ganesan, S., Subramanian, S., \& Anandhakumar, R. (2014). Source and transmission line maintenance outage scheduling in a power system using teaching learning based optimization algorithm. Applied Soft Computing,21, 72-83.

Agrawal, S., Sharma, S., \&Silakari, S. (2015). Teaching learning based optimization (TLBO) based improved iris recognition system. Advances in Intelligent Systems and Computing,330, 735-740.

Akin, A., \&Aydogdu, I. (2015). Optimum design of steel space frames by hybrid teaching-learning based optimization and harmony search algorithms. World Academy of Science, Engineering and Technology Civil and Environmental Engineering, 2(7), 739-745.

Alneamy, J.S.M, \& Alnaish, R.A.H (2014), Heart disease diagnosis utilizing hybrid fuzzy wavelet neural network and teaching learning based optimization algorithm. Advances in Artificial Neural Systems, http://dx.doi.org/10.1155/2014/796323.

Amiri, B. (2012). Application of teaching-learning-based optimization algorithm on cluster analysis. Journal of Basic Applied Science Research, 2(11),11795-11802. 
Arya, L.D., \& Koshti, A. (2014). Anticipatory load shedding for line overload alleviation using teaching learning based optimization (TLBO). International Journal of Electrical Power \& Energy Systems,63, 862-877.

Aydogdu, I., \& Akin, A. (2014).Teaching and learning-based optimization algorithm for optimum design of steel buildings. Computing in Civil and Building Engineering, 2(7), 2167-2175.

Babu, B.S., \& Palaniswami, S. (2015). Teaching learning based algorithm for OPF with DC link placement problem. International Journal of Electrical Power \& Energy Systems, 73, 773-781.

Baghlani, A. (2014). Water level stabilization in open channels using Chebyshev polynomials and teaching-learning-based optimization, Journal of Hydroinformatics, 16(5), 1097-1109

Baghlani, A., \& Makiabadi, M.H. (2013). Teaching-learning-based optimization algorithm for shape and size optimization of truss structures with dynamic frequency constraints. IJST Transactions of Civil Engineering, 37(1), 409-421.

Banerjee, S., Maity, D., \& Chanda, C.K. (2015). Teaching learning based optimization for economic load dispatch problem considering valve point loading effect. International Journal of Electrical Power \& Energy Systems, 73, 456-464.

Barisal, A.K. (2015). Comparative performance analysis of teaching learning based optimization for automatic load frequency control of multi-source power systems. Electrical Power and Energy Systems, 66, 67-77.

Bayat, E. \& Delavari, H. (2015). Performance Evaluation of power system stabilizers using teaching learning based optimization of a multi-machine system,Cumhuriyet Science Journal, 36(3), 24052411.

Bayram, A., Uzlu, E., Kankal, M., \& Dede, T. (2015). Modeling stream dissolved oxygen concentration using teaching-learning based optimization algorithm. Environmental Earth Sciences,73(10), 65656576.

Baykasoğlu, A., Hamzadayi, A., \& Köse, S.Y. (2014). Testing the performance of teaching-learning based optimization (TLBO) algorithm on combinatorial problems: Flowshop and job shop scheduling cases. Information Sciences, 276(20), 204-218.

Bhattacharjee, K., Bhattacharya, A. \& Halder, S. (2014). Teaching-learning-based optimization for different economic dispatch problems. Scientia Iranica, 21(3), 870-884.

Biswas, S., Kundu, S., Bose, D., \& Das, S. (2012). Cooperative co-evolutionary teaching-learning based algorithm with a modified exploration strategy for large scale global optimization. Swarm, Evolutionary, and Memetic Computing, Lecture Notes in Computer Science, 7677, 467-475.

Bouchekara, H.R.E.H., Abido, M.A., \& Boucherma, M. (2014). Optimal power flow using teachinglearning-based optimization technique. ElectricPower Systems Research,114, 49-59.

Boudjefdjouf, H., Mehasni, R., Orlandi, A., Bouchekara, H.R.E.H., de Paulis, F., \& Smail, M.K. (2015). Diagnosis of multiple wiring faults using time-domain reflectometry and teaching-learningbased optimization. Electromagnetics,35, 10-24.

Camp, C.V., \& Farshchin, M. (2014). Design of space trusses using modified teaching-learning-based optimization. Engineering Structures, 62-63, 87-97.

Cao, J., \& Luo, J. (2015). A study on SVM based on the weighted elitist teaching-learning-based optimization and application in the fault diagnosis of chemical process. MATEC Web of Conferences, doi: 10.1051/matec.com/2505016.

Chakravarthy, V.V.S.S.S., Sarma, S.V.R.A.N, Babu K.N., Chowdary, P.S.R., \& Kumar, S.T. (2015). Non-uniform circular array synthesis using teaching learning based optimization. Journal of Electronics and Communication Engineering, doi:10.6084/m9.figshare.1452770.

Chandra, E., \& Sujiya, S. (2014). Tamil speech recognition using hybrid technique of EWTLBO and HMM. International Journal of Computer Science and Information Technologies, 5(5), 6664-6669.

Charak, A. (2014). Optimal scheduling of multi-chain hydrothermal system using teaching-learning based optimization. M.Tech. Thesis, Thapar University, Punjab-India.

Chaves-González, J.M., Pérez-Toledano, M.A., \& Navasa, A. (2015). Teaching learning based optimization with Pareto tournament for the multiobjective software requirements selection. Engineering Applications of Artificial Intelligence, 43, 89-101. 
Chen, X., Luo, Z., He, X., \& Zhu, L. (2014).Thinning and weighting of planar arrays by modified teaching learning based optimization algorithm. Journal of Electromagnetic Waves and Applications,28(15), 1924-1934.

Chen, D., Zou, F., Wang, J., \& Yuan, W. (2015a). A teaching-learning-based optimization algorithm with producer-scrounger model for global optimization. Soft Computing,19, 745-762.

Chen, D., Zou, F., Wang, J., \& Yuan, W. (2015b). SAMCCTLBO: a multi-class cooperative teachinglearning-based optimization algorithm with simulated annealing. Soft Computing, doi:10.1007/s00500-015-1613-9

Chen, T., Hong, Z., Deng, F-a., Yang, X., Wei, J., \& Cui, M. (2015c). A novel selective ensemble classification of microarray data based on teaching-learning-based optimization. International Journal of Multimedia and Ubiquitous Engineering, 10(6), 203-218.

Chen, D., Lu, R., Zou, F., \& Li, S. (2015d). Teaching-learning-based optimization with variablepopulation scheme and its application for ANN and global optimization. Neurocomputing, doi:10.1016/j.neucom.2015.08.068.

Chen, D., Zou, F., Li, Z., Wang, J., \& Li, S. (2015e). An improved teaching-learning-based optimization algorithm for solving global optimization problem. Information Sciences, 297, 171190.

Cheng, Y-H. (2013). A novel optimization method for picking PCR oligonucleotide primers. International Journal of Computer Science and Electronics Engineering, 1(4), 518-523.

Cheng, Y-H. (2014). Computational intelligence-based polymerase chain reaction primer selection based on a novel teaching-learning-based optimization.IET Nanobiotechnology,8(4), 238246.

Cheng, Y-H. (2015a). Estimation of teaching-learning-based optimization primer design using regression analysis for different melting temperature calculations. IEEE Transactions on Nanobioscience, 14(1), 1-9.

Cheng, Y-H. (2015b). A novel teaching-learning based optimization for improved mutagenic primer design in mismatch PCR-RFLP SNP genotyping. IEEE/ACM Transactions on Computational Biology and Bioinformatics, doi:10.1109/tcbb.2015.2430354.

Cho, J.H., \& Kim, Y.T. (2015). Optimal design of electromagnet for Maglev vehicles using hybrid optimization algorithm. Soft Computing,19, 901-907.

Crawford, B., Soto, R., Aballay, F., Misra, S., Johnson, F., \& Paredes, F. (2015). A teaching-learningbased optimization algorithm for solving set covering problems. Computational Science and Its Applications-ICCSA 2015, Lecture Notes in Computer Science, 421-430.

Črepinšek, M., Liu, S-H, \& Mernik, L. (2012). A note on teaching-learning-based optimization algorithm.Information Sciences, 212, 79-93.

Črepinšek, M., Liu, S-H, Mernik, L., \& Mernik, M. (2014). Is a comparison of results meaningful from the inexact replications of computational experiments? Soft Computing, doi:10.1007/s00500-0141493-4.

Daljit, K., \& Ranjit, K. (2013). A design of IIR based digital hearing aids using teaching-learning-based optimization. International Journal of Computer Engineering \& Applications, 3(2-3), 180-190.

Das, S. P., \& Padhy, S. (2015). A novel hybrid model using teaching-learning-based optimization and a support vector machine for commodity futures index forecasting. International Journal of Machine Learning and Cybernetics,doi:10.1007/s13042-015-0359-0.fs.

Dede, T. (2013). Optimum design of grillage structures to LRFD-AISC with teaching-learning based optimization. Structure and Multidisciplinary Optimization,48(5), 955-964.

Dede, T. (2014). Application of teaching-learning-based-optimization algorithm for the discrete optimization of truss structures. KSCE Journal of Civil Engineering,18(6), 1759-1767.

Dede, T., \& Ayvaz, Y. (2015). Combined size and shape optimization of structures with a new metaheuristic algorithm. Applied Soft Computing,28, 250-258.

Degertekin, S.O., \& Hayalioglu, M.S. (2013). Sizing truss structures using teaching learning based optimization. Computers \& Structures, 119(1), 177-188. 
Dib, N., \& Sharaqa, A. (2014). Synthesis of thinned concentric circular antenna arrays using teachinglearning-based optimization. International Journal of $R F$ and Microwave Computer-Aided Engineering, 24(4), 443-450.

Dixit, G., \& Mishra, S.K. (2014). Comparison of teaching learning based optimization method and taguchi method by analysing force in turning by single point cutting tool. International Journal for Scientific Research \& Development, 2(10), 712-716.

Dokeroglu, T. (2015). Hybrid teaching-learning-based optimization algorithm for the quadratic assignment problem. Computers \& Industrial Engineering,85, 86-101.

Durai, S., Subramanian, S., \& Ganesan, S. (2015). Improved parameters for economic dispatch problems by teaching-learning-based optimization. International Journal of Electrical Power \& Energy Systems,67, 11-24.

Dwived, S., Mishra, V., \& Kosta Y (2015). Application of Teaching Learning Based Optimization in antenna designing. aemjournal.org/index.php/AEM/article/download/255/pdf_55.

Ganesh, B.S., \& Reddy, A.S. (2014). Teaching learning based optimization for economic dispatch problem with valve point loading effect. International Journal of Education and Applied Research, 4(1), 9-15.

Ganguly, A., \& Patel, S.K. (2014). A teaching-learning-based optimization approach for economic design of X-bar control chart. Applied Soft Computing,24, 643-653.

García, J.A.M., \&Mena, A.J.G.(2013). Optimal distributed generation location and size using a modified teaching-learning-based optimization algorithm. International Journal of Electrical Power \& Energy Systems, 50, 65-75.

Ghasemi, M., Ghanbarian, M.M., Ghavidel, S., Rahmani, S., \& Moghaddam, E.M. (2014). Modified teaching learning algorithm and double differential evolution algorithm for optimal reactive power dispatch problem: A comparative study. Information Sciences,278, 231-249.

Ghasemi, M., Ghavidel, S., Rahmani, S., Roosta, A., \& Falah, H. (2015). A novel hybrid algorithm of imperialist competitive algorithm and teaching learning algorithm for optimal power flow problem with non-smooth cost functions. Engineering Applications of Artificial Intelligence,29, 54-69.

Gonzalez-Alvarez, D.L., Vega-Rodriguez, M.A., Gomez-Pulido, J.A., \& Sanchez-Perez, J.M. (2012). Multiobjective teaching-learning-based optimization (MO-TLBO) for motiffinding. $13^{\text {th }}$ IEEE International Symposium on Computational Intelligence and Informatics, Budapest, Hungary, doi:10.1109/cinti.2012.6496749.

González-Álvarez, D.L., Vega-Rodríguez, M.A., Gómez-Pulido, J.A., \& Sánchez-Pérez, J.M. (2014). PredictingDNA motifs by using evolutionary multiobjective optimization. IEEE Transactions on Systems, Man and Cybernetics Part C: Applications and Reviews, 1-13.

Govardhan, M,, \& Roy, R. (2015). Ecomomic analysis of unit commitment with distributed energy resources. International Journal of Electrical Power \& Energy Systems,71, 1-14.

Harik, G.R., \&Lobo, F. (1999). A parameter-less genetic algorithm. Technical Report, University of Illinois at Urbana-Champaign.

Hoseini, M., Hosseinpour, H., \& Bastaee, B. (2014). A new multi objective optimization approach in distribution systems. Optimization Letters,8, 181-199.

Hosseinpour, H., \& Bastaee, B. (2015). Optimal placement of on-load tap changers in distribution networks using SA-TLBO method. International Journal of Electrical Power \& Energy Systems,64, 1119-1128.

Huang, J., Gao, L., \& Li, X. (2015). A teaching-learning-based cuckoo search for constrained engineering design problems. Advances in Global Optimization,95, 375-386.

Huang, J., \& Gao, L., \& Xinyu, L. (2015). An effective teaching-learning-based cuckoo search algorithm for parameter optimization problems in structure designing and machining processes. Applied Soft Computing,36, 349-356.

Hwang, H-L., Chiang Y-C., Lin, Y.-D., Chuang, L-Y., \& Yang, C-H. (2014). A teaching-learning-based optimization for operationon prediction. Asian Journal of Engineering and Technology, 2(5), 375379. 
Jiang, X., \& Zhou, J. (2013). Hybrid DE-TLBO algorithm for solving short term hydro-thermal optimal scheduling with incommensurable Objectives, Proceedings of IEEE $32^{\text {nd }}$ Chinese Control Conference, 26-28 July, Xi'an, 2474-2479.

Jordehi, A.R. (2014). Optimal setting of TCSCs in power systems using teaching-learning-based optimisation algorithm. Neural Computing and Applications.doi:10.1007/s00521-014-1791-X

Kadambur, R., \& Kotecha, P. (2015). Multi-level production planning in a petrochemical industry using elitist teaching-learning-based-optimization. Expert Systems with Applications,42, 628-641.

Kanwar, N., Gupta, N., Niazi, K.R., \& Swarnkar, A. (2015). Simultaneous allocation of distributed resources using improved teaching learning based optimization. Energy Conversion and Management, 103, 387-400.

Keesari, H.S., \&Rao, R.V. (2014). Optimization of job shop scheduling problems using teachinglearning-based optimization algorithm. OPSEARCH,51(4), 545-561.

Krishnanand, K.R., Hasani, S.M.F, Panigrahi, B.K., \& Panda S.K. (2013). Optimal power flow solution using self-evolving brain-storming inclusive teaching-learning-based algorithm. In: Proceeding of International Conference on Swarm Intelligence, Lecture Notes in Computer Science,7928, 338345.

Krishnasamy, U., \& Nanjundappan, D. (2014). A refined teaching-learning based optimization algorithm for dynamic economic dispatch of integrated multiple fuel and wind power plants. Mathematical Problems in Engineering,doi:10.1155/2014/956405.

Kumar, A., Kumar, V. R., Datta, S., \& Mahapatra, S.S. (2015). Parametric appraisal and optimization in machining of CFRP composites by using TLBO (teaching-learning based optimization algorithm). Journal of Intelligent Manufacturing, doi:10.1007/s10845-015-1050-8.

Kumar , K.S., \& Samuel, R.H. (2015). Teaching Learning based Optimization. International Journal for Innovative Research in Science \& Technology, 1(11), 413-419.

Kumar, V.R. (2013). Teaching learning based optimization applied to mechanical constrained design problems. M.Tech. Thesis, NIT Rourkela, India.

Kundu, S., Biswas, S., Das, S., \& Bose, D. (2012). Selective teaching-learning based niching technique with local diversification strategy. Swarm, Evolutionary and Memetic Computing, Lecture Notes in Computer Science, 7677, 160-168.

Kurada, R.R., Pavan, K.K., \&Rao, A.A. (2015). Automatic teaching-learning-based optimization: A novel clustering method for gene functional enrichments. Computational Intelligence Techniques for Comparative Genomics, SpringerBriefs in Applied Sciences and Technology, doi:10.1007/978981-287-338-5_217-35.

Lahari, K., Murty, M.R., \& Satapathy, S.C. (2015). Partition Based Clustering Using Genetic Algorithm and Teaching Learning Based Optimization: Performance Analysis. Proceedings of the $49^{\text {th }}$ Annual Convention of the Computer Society of India, 338, 191-200.

Li, G., Niu, P., s, W., \& Liu, Y. (2013). Model NOx emissions by least squares support vector machine with tuning based on ameliorated teaching-learning-based optimization. Chemometrics and Intelligent Laboratory Systems, 126, 11-20.

Li, J., Pan, Q., \& Mao, K. (2015). A discrete teaching-learning-based optimisation algorithm for realistic flowshop rescheduling problems. Engineering Applications of Artificial Intelligence,37, 279-292.

Lim, W.H., \& Isa, N.A.M. (2014a). Teaching and peer-learning particle swarm optimization. Applied Soft Computing,18, 39-58.

Lim, W.H., \& Isa, N.A.M. (2014b). Bidirectional teaching and peer-learning particle swarm optimization. Information Sciences,280, 111-134.

Lin, W., Yu, D.Y., Wang, S., Zhang, C., Zhang, S., Tian, H., Luo M., \&Liu, S. (2014). Multiobjective teaching-learning-based optimization algorithm for reducing carbon emissions and operation time in turning operations. Engineering Optimization, doi:10.1080/0305215X.2014.928818, 
Lin, W., Yu, D.Y., Zhang, C., Liu, X., Zhang, S., Tian, Y., Liu, S., \& Xie, Z. (2015). A multi-objective teaching-learning-based optimization algorithm to scheduling in turning processes for minimizing makespan and carbon footprint. Journal of Cleaner Production, 101, 337-347.

Luo, Z., Chen X., \& He, X. (2014). Synthesis of thinned square array using modified teaching-learningbased optimization algorithm. Proceedings of ISAP 2014, Kaohsiung, Taiwan, doi:10.1109/isanp.2014.7026572.

Makiabadi, M.H., Baghlani, A., Rahnema, H., \& Hadianfard, M.A. (2013). Optimal design of truss bridges using teaching-learning-based optimization algorithm. International Journal of Optimization in Civil Engineering, 3(3), 499-510.

Mandal, B., \& Roy, P.K. (2013). Optimal reactive power dispatch using quasi oppositional teaching learning based optimization. Electrical Power and Energy Systems,53, 123-134.

Mandal, B., \& Roy, P.K. (2014). Multiobjective optimal power flow using quasi-oppositional teaching learning based optimization. Applied Soft Computing,21, 590-606

Mardaneh, M., \&Golestaneh, F. (2014). Harmonic optimization of diode-clamped multilevel inverter using teaching-learning-based optimization algorithm. IETE Journal of Research,59(1), 9-16.

Medina, M.A., Coello, C.A.C., \& Ramirez, J.M. (2013). Reactive Power Handling by a Multiobjective Teaching LearningOptimizer Based on Decomposition. IEEE Transactions on Power Systems,28(4), 3629-3637.

Medina, M.A., Juan, M., Ramirez, Carlos, A., Coello, \& Das, S. (2014). Use of a multi-objective teaching-learning algorithm for reduction of power losses in a power test system. DYNA, 81(185), 204-221.

Mernik, M., Liu, S-H, Karaboga, D., \& Črepinšek, M. (2015). On clarifying misconceptions when comparing variants of the Artificial Bee Colony Algorithm by offering a new implementation. Information Sciences, 291, 115-127.

Moghadam, A., \& Seifi, A.R. (2014). Fuzzy-TLBO optimal reactive power control variables planning for energy loss minimization. Energy Conversion and Management,77, 208-215.

Mohapatra, A., Panigrahi, B.K., Singh, B., \&Bansal, R. (2012). Optimal placement of capacitors in distribution networks using a modified teaching-learning based algorithm. Swarm, Evolutionary, and Memetic Computing, Lecture Notes in Computer Science, 7677, 484-490.

Mukhopadhyay, P., Roy, B.C., Dutta, S., \& Roy, P.K. (2015). Optimal location of TCSCusing opposition teaching learning based optimization. International Journal of Energy Optimization and Engineering, 4(1), 708-224.

Murty, M.R., Naik, A., Murthy, J.V.R., Reddy, P.V.G.D.P., Satapathy, S.C., \& Parvathi, K. (2014). Autoclustring using teaching learning based optimization. Applied Mathematics, 5, 1202-1211.

Niknam, T., Bahareh, B., Mirzaei, B.M., \&Bahmani, F.B. (2015). A new teaching-learning-based optimization algorithm for distribution system state estimation. Journal of Intelligent \& Fuzzy Systems, doi: 10.3233/IFS-141579.

Niknam, T., Rasoul, A.A., \& Narimani, M.R. (2012a).A new multi objective optimization approach based on TLBO for location of automatic voltage regulators in distribution systems. Engineering Applications of Artificial Intelligence, 25, 1577-1588.

Niknam, T., Rasoul, A.A., \& Narimani, M.R. (2012b). An efficient scenario-based stochastic programming framework for multi-objective optimal micro-grid operation. Applied Energy,99, 455470.

Niknam, T., Rasoul, A.A., \& Aghaei, J. (2013). A new modified teaching-learning algorithm for reserve constrained dynamic economic dispatch. IEEE Transactions on Power Systems,28(2), 749-763.

Omidvar, M., Fard, R.K., Sohrabpoor, H., \& Teimouri, R. (2015). Selection of laser bending process parameters for maximal deformation angle through neural network and teaching-learning-based optimization algorithm. Soft Computing,19, 609-620.

Ouyang, H-b., Gao, L-q., Kong, X-y., Zou, D-x., \& Li, S. (2015). Teaching-learning based optimization with global crossover for global optimization problems. Applied Mathematics and Computation, 265, 533-556. 
Papa, G. (2008). Parameter-less evolutionary search. Proceedings of Genetic and Evolutionary Computation Conference, 1133-1134.

Papa, G.,Vukašinovi c, V.,\&Korošec, P. (2012). Guided restarting local searchfor production planning. Applications of Artificial Intelligence,25, 242-253.

Patel, S.J., Panchal, A.K., \& Kheraj, V. (2014). Extraction of solar cell parameters from a single current-voltage characteristic using teaching learning based optimization algorithm. Applied Energy,119, 384-393.

Pawar, P.J., \&Rao, R.V. (2013a). Parameter optimization of machining processes using teachinglearning-based optimization algorithm. International Journal of Advanced Manufacturing Technology,67(5-8), 995-1006.

Pawar, P.J., \& Rao, R.V. (2013b). Erratum to: Parameter optimization of machining processes using teaching-learning-based optimization algorithm. International Journal of Advanced Manufacturing Technology,67(5-8), 1955.

Pholdee, N., Park, W.W., Kim, D.K., Im Y T, Bureerat S, Kwon H.C., \& Chun M.S. (2014) Efficient hybrid evolutionary algorithm for optimization of a strip coiling process. Engineering Optimization, 47(4), 521-532.

Rajaram, D., Akhria, H., \& Omkar, S.N. (2015). Airfoil topology optimization using teaching-learning based optimization.International Journal of Applied Metaheuristic Computing, doi:10.4018/ijamc.2015010102.

Rajasekhar, A., Rani, R., Ramya, K., \& Abraham, A. (2012). Elitist teaching learning opposition based algorithm for global optimization, Proceedings of IEEE International Conference on Systems, Man, and Cybernetics, Seoul, doi:10.1109/icsmc.2012.6377882.

Ramanand, K.R., Krishnanand, K.R., Panigrahi, B.K., \&Kuma, M. (2012). Brain storming incorporated teaching-learning-based algorithm with application to electric power dispatch. Swarm, Evolutionary, and Memetic Computing, Lecture Notes in Computer Science, 7677, 476-483.

Ramoji, S.K., \& Kumar, B.J. (2014). Optimal economical sizing of a PV-wind hybrid energy system using genetic algorithm and teaching learning based optimization. International Journal of Advanced Research in Electrical, Electronics and Instrumentation Engineering, 3(2), 7352-7367.

Rao, C.S., Pavan, K.K., \& Rao, A.A. (2013). An automatic medical image segmentation using teaching learning based optimization. Proceedings of International Conference on Advances in Computer Science, doi:02.aetacs.2013.4.99.

Rao, K.V., Omkar, S.N., \& Jagdeesh, G. (2013). Scramjet inlet design using Teaching Learning Based Optimization (TLBO). International Conference on Advanced Materials, Manufacturing, Management \& Thermal Sciences, http://www.aero.iisc.ernet.in/content/scramjet-inlet-designusing-teaching-learning-based-optimization-tlbo.

Rao, R.V. (2015). Teaching Learning Based Optimization and its Engineering Applications. London: Springer-Verlag.

Rao, R.V., \& Kalyankar, V.D.(2014). Optimization of abrasive flow machining process. Introduction to Micromachining (Ed. V.K.Jain), New Delhi: Narosa Publishing House.

Rao, R.V., Kalyankar, V.D. (2013a). Multi-pass turning process parameter optimization using teaching-learning-based optimization algorithm. Scientia Iranica, 20(3), 967-974.

Rao, R.V., \& Kalyankar, V.D. (2013b). Parameter optimization of modern machining processes using teaching-learning-based optimization algorithm. Engineering Applications of Artificial Intelligence, 26, 524-531.

Rao, R.V., Kalyankar, V.D., \& Waghmare, G. G.(2014). Parameters optimization of selected casting processes using teaching-learning-based optimization algorithm. Applied Mathematical Modelling,38, 5592-5608.

Rao, R.V., \& More, K.C. (2014). Advanced optimal tolerance design of machine elements using teachinglearning-based optimization algorithm. Production \& Manufacturing Research: An Open Access Journal,2(1), 71-94.

Rao, R.V., \& More, K.C. (2015). Optimal design of the heat pipe using TLBO (teaching-learning-based optimization) algorithm. Energy,80, 535-544. 
Rao, R.V., \& Patel, V. (2012). An elitist teaching-learning-based optimization algorithm for solving complex constrained optimization problems. International Journal of Industrial Engineering Computations,3(4), 535-560.

Rao, R.V., \& Patel, V. (2013a). Comparative performance of an elitist teaching-learning-based optimization algorithm for solving unconstrained optimization problems. International Journal of Industrial Engineering Computations,4(1), 29-50.

Rao, R.V., \& Patel, V. (2013b). Multiobjective optimization of heat exchangers using a modified teaching-learning-based optimization algorithm. Applied Mathematical Modelling, 37, 1147-1162.

Rao, R.V., \& Patel, V. (2013c). Multiobjective optimization of two stage thermoelectric cooler using a modified teaching-learning-based optimization algorithm. Engineering Applications of Artificial Intelligence, 26, 430-445.

Rao, R.V., \& Patel, V. (2013d). An improved teaching-learning-based optimization algorithm for solving unconstrained optimization problems. Scientia Iranica, 20(3), 710-720.

Rao, R.V., \& Patel, V. (2014). A multiobjective improved teaching-learning based optimization algorithm for unconstrained and constrained optimization problems. International Journal of Industrial Engineering Computations5(1), 1-22.

Rao, R.V., \& Rai, D.P. (2015a). Optimization of fused deposition modeling process using teachinglearning-based optimization algorithm. Engineering Science and Technology: An International Journal (in press).

Rao, R.V., \& Rai, D.P. (2015b). Optimization of advanced finishing processes using teaching-learningbased optimization algorithm. Nanofinishing Science and Technology (Ed. V.K.Jain), New York: Taylor and Francis.

Rao, R.V., \& Savsani, V.J. (2012). Mechanical Design Optimization using Advanced Optimization Techniques. New York: Springer-Verlag.

Rao, R.V., \& Savsani, V.J. (2011). Multiobjective design optimization of a robot gripper using TLBO technique. Proceedings of the Second Indo-Russian Joint Workshop on Computational Intelligence, Modern Heuristics in Automation and Robotics, Novosibirsk State Technical University, Russia, 1013 September, 184-188.

Rao, R.V., Savsani, V.J., \& Vakharia, D.P. (2011). Teaching-learning-based optimization: A novel method for constrained mechanical design optimization problems. Computer-Aided Design,43, 303315.

Rao, R.V., Savsani, V.J., \& Vakharia, D.P. (2012a). Teaching-Learning-Based Optimization: An optimization method for continuous non-linear large scale problems. Information Sciences, 183, 115.

Rao, R.V., Savsani, V.J., \&Balic, J. (2012b). Teaching-learning-based optimization algorithm for unconstrained and constrained real-parameter optimization problems. Engineering Optimization, 44(12), 1447-1462.

Rao, R.V., \& Waghmare, G.G. (2013). Solving Composite Test Functions Using Teaching-LearningBased Optimization Algorithm. Proceedings of the International Conference on Frontiers of Intelligent Computing: Theory and Applications (FICTA), Advances in Intelligent Systems and Computing, Bhubaneswar, 199, 395-403.

Rao, R.V., \& Waghmare, G.G. (2014a). A comparative study of a teaching-learning-based optimization algorithm on multiobjective unconstrained and constrained functions. Journal of King Saud University-Computer and Information Sciences, 26, 332-346.

Rao, R.V., \& Waghmare, G.G. (2014b). Thermoeconomic optimization of a shell and tube condenser using teaching-learning-based optimization algorithm. Proceedings of $3^{\text {rd }}$ International Conference on Recent Trends in Engineering \& Technology, Chandwad, India, 28-30 March 2014, 498-503.

Rao, R.V., \&Waghmare G. (2015a). Design optimization of robot grippers using teaching-learning based optimization algorithm. Advanced Robotics, 29(6), 431-447.

Rao, R.V., \& Waghmare, G. (2015b). Optimization of thermal performance of a smooth flat-plate solar air heater using teaching-learning-based optimization algorithm. Cogent Engineering,2(1), 1-28. 
Rao, R.V., \& Waghmare, G.G. (2015c). Multiobjective design optimization of a plate-fin heat sink using a teaching-learning-based optimization algorithm. Applied Thermal Engineering,76, 521-529.

Rasoul, A.A., Niknam, T., Roosta, A., Malekpour, A.R., \& Zarea, M. (2012). Probabilistic multiobjective wind-thermal economic emission dispatch based on point estimated method. Energy,37, 322-335.

Recioui, A., Bentarzi, H., \& Ouadi, A. (2015). Application of a binary teaching learning-based algorithm to the optimal placement of phasor measurement units. Progress in Clean Energy, 1, 817830.

Roy, A., Dutta, S., Roy, B.C., Roy, \& P.R. (2015). Load frequency control of interconnected power system using teaching learning based optimization. International Journal of Energy Optimization and Engineering, doi:10.4018/ijeoe.2015010107.

Roy, P.K. (2013). Teaching learning based optimization for short-term hydrothermal scheduling problem considering valve point effect and prohibited discharge constraint. International Journal of Electrical Power \& Energy Systems, 53, 10-19.

Roy, P.K., \& Bhui, S. (2014). Multiobjective quasi-oppositional teaching learning based optimization for economic emission load dispatch problem. Electrical Power and Energy Systems,53, 937-948.

Roy, P.K., Paul, C., \& Sultana, S. (2014). Oppositional teaching learning based optimization approach for combined heat and power dispatch. Electrical Power and Energy Systems,57, 392-403.

Roy, P.K., \& Sarkar, R. (2014). Solution of unit commitment problem using quasi-oppositional teaching learning based algorithm. Electrical Power and Energy Systems,60, 96-106.

Sahoo, S., Murty, S.B., \& Krishna, K.M. (2014). Character recognition using teaching learning based optimization. Proceedings of the $3^{\text {rd }}$ International Conference on Frontiers of Intelligent Computing: Theory and Applications, 327, 737-744.

Sahu, A., Panigrahi, S.K., Pattnaik, S.,\&Dutta, S.R. (2013). Data classification based on teachinglearning based optimization. International Conference on Intelligent Infrastructure, http://hdl.handle.net/123456789/469.

Sahu, B.K., Pati, S., Mohanty, P.K., \& Panda, S. (2015a). Teaching-learning based optimization algorithm based fuzzy-PID controller for automatic generation control of multi-area power system. Applied Soft Computing,27, 240-249.

Sahu, R.K., Gorripotu, T.S., \&Panda, S. (2015b). Automatic generation control of multi-area power systems with diverse energy sources using teaching learning based optimization algorithm. Engineering Science and Technology, An International Journal, doi:10.1016.j.jestech.2015.07.011.

Samet, H., Abdollah K-F., \& Sina, R. (2015). A modified teaching-learning based optimization for the location and size of two SVCs to compensate the railway's voltage drop. http://pe.org.pl/articles/2015/1/7.pdf.

Sandeep, U., Omane, R., \& Pawar, A. (2015). GPGPU based teaching learning based optimization and artificial bee colony algorithm for unconstrained optimization problems. 2015 IEEE International Advanced Computing Conference, June 12-13, Bangalore, India. doi: 10.1109/iadcc.2015.7154866.

Satapathy, S.C.,\& Naik, A. (2015). A modified teaching-learning-based optimization (mTLBO) for global search.Recent Patents on Computer Science, 6(1), 60-72.

Satapathy, S.C., \& Naik, A. (2013). Cooperative teaching-learning based optimisation for global function optimisation. International Journal of Applied Research on Information Technology and Computing, 4(1), 1-17.

Satapathy, S.C., \& Naik, A. (2012). Improved teaching learning based optimization for global function optimization. Decision Science Letters,2, 23-34.

Satapathy, S.C., \& Naik, A. (2014). Modified teaching-learning-based optimization algorithm for global numerical optimization-A comparative study. Swarm and Evolutionary Computation,16, 28-37.

Satapathy, S.C., \& Naik, A., Parvathi, K. (2013a). A teaching learning based optimization based on orthogonal design for solving global optimization problems. Springer Plus,2(130), 1-12.

Satapathy, S.C., Naik, A., \& Parvathi, K. (2013b). Weighted teaching-learning-based optimization for global function optimization. Applied Mathematics, 4, 429-439. 
Satapathy, S.C., Naik, A., \&Parvathi, K. (2013c). Unsupervised feature selection using rough set and teaching learning-based optimization. International Journal of Artificial intelligence and Soft Computing, 3(3), 244-256.

Sayare, R.S., \& Kamble, A.G. (2015). Parameter optimization of composite leaf spring using TLBO algorithm. The First Mechanical Engineering Post Graduate Students' Conference, http://openpgcon.org/index.php/Mech/mechcon/paper/view/1315.

Shabanpour-Haghighi, A., Seifi, A.R., \& Niknam, T. (2014). A modified teaching learning based optimization for multiobjective optimal power flow problem. Energy Conversion and Management, 77, 597-607.

Sharma, S., Arya, L.D., \& Katiyal, S. (2015). Performance comparison of teaching-learning-based optimization and particle swarm optimization algorithms applied to the design of adaptive channel equalizer. IUP Journal of Telecommunications, http://www.iupindia.in/1508/Telecommunications/Performance_Comparison.html.

Singh, D., \& Dhillon, J.S. (2015). Design of optimal IIR digital filter using Teaching-Learning based optimization technique. WSEAS Transactions on Advances in Engineering Education, 12, 9-18.

Singh, M., Panigrahi, B.K., \& Abhyankar, A.R. (2013). Optimal coordination of directional overcurrent relays usingteaching-learning-based optimization (TLBO) algorithm. International Journal of Electrical Power \& Energy Systems,50, 33-41.

Singh, R., \&Verma, H.K. (2013).Teaching-learning-based optimization algorithm for parameter identification in the design of IIR filters. Journal of The Institution of Engineers (India): Series B, 94(4), 285-294.

Siripuram, R., \& Kumar, D.M.V. (2014). Optimal sizing and location of distributed generation using improved teachinglearning based optimization algorithm. International Journal of Advanced Technology \& Engineering Research, 116-123.

Sreenivas, T. B., Rajasekhar, A., \& Abraham, A. (2013). An optimal design of coordinated PI based PSS with TCSC controller using modified teaching learning based optimization. $5^{\text {th }}$ World Congress on Nature and Biologically Inspired Computing, Fargo, North Dakota, USA, doi 10.1109/NaBIC.2013.6617845.

Sreenivasulu, R.A, Sreenath, K., \& Abdul S.M. (2014). Generation of alternative process plans using TLBO algorithm. International Journal of Engineering Research and General Science, 2(3), 14-20.

Subramanian, S., Abirami, M., \& Ganesan, S. (2015). Reliable/cost-effective maintenance schedules for a composite power system using fuzzy supported teaching learning algorithm. IET Generation, Transmission \& Distribution, 9(9), 805-819.

Sultana, S., \& Roy, P.K. (2014). Multiobjective quasi-oppositional teaching learning based optimization for optimal location of distributed generator in radial distribution systems. Electrical Power and Energy Systems,63, 534-545.

Tang, D., Zhao, J., \& Li, H (2013). An improved teaching-learning-based optimization algorithm with memetic method for global optimization. International Journal of Advancements in Computing Technology, 5(9) 942-949.

Tiwary, A., Arya, L.D., Arya, R., \&Choube, S.C. (2015). Inspection-repair based availability optimization of distribution systems using teaching learning based optimization. Journal of The Institute of Engineers (India): Series B. doi:10.1007/s40031-015-0196-2

Theja, B.S., \& Rajasekhar, A. (2013). An optimal design of coordinated PI based PSS with TCSC controller using modified teaching learning based optimization. Proceedings of World Congress on Nature and Biologically Inspired Computing, doi:10.1109/NaBIC.2013.6617845.

Toğan, V. (2013). Design of pin jointed structures using teaching-learning based optimization. Structural Engineering and Mechanics, 47(2), 209-225.

Toğan, V. (2012). Design of planar steel frames using teaching-learning based optimization. Engineering Structures,34, 225-234.

Tuncel, G., \& Aydin, D. (2014). Two-sided assembly line balancing using teaching-learning-based optimization algorithm. Computers \& Industrial Engineering,74,291-299. 
Tuo, S., Yong, L., \& Zhou, T. (2013). An improved harmony search based on teaching-learning strategy for unconstrained optimization problems. Mathematical Problems in Engineering, http://dx.doi.org/10.1155/2013/413565.

Turgut, O.E., \& Coban, M.T. (2015). Optimal proton exchange membrane fuel cell modelling based on hybrid Teaching Learning Based Optimization - Differential Evolution algorithm. Ain Shams Engineering Journal, doi:10.1016.j.asej.2015.05.003.

Umbarkar, A.J., Rothe, A.M., \&Sathe, A.S. (2015). OpenMP Teaching-Learning Based Optimization Algorithm over Multi-Core System. Intelligent Systems and Applications, 7, 57-65

Uzlu, E.,Komurcu, M.I., Kankal, M., Dede, T., \& Ozturk, H.T. (2014a). Prediction of berm geometry using a set of laboratory tests combined with teaching-learning-based optimization and artificial bee colony algorithms. Applied Ocean Research,48, 103-113.

Uzlu, E., Kankal, M., Akpinar, A., \&Dede, T. (2014b). Estimates of energy consumption in Turkey using neural networks with the teaching-learning-based optimization algorithm. Energy,75, 295303.

Waghmare, G. (2013). Comments on “A Note on Teaching Learning Based Optimization Algorithm”. Information Sciences, 229, 159-169.

Wang, K.L., Wang, H.B., Yu, L.X., Ma, X.Y., \& Xue, Y.S. (2013). Teaching-learning-based optimization algorithm for dealing with real-parameter optimization problems. Applied Mechanics and Materials, 380-384, 1342-1345.

Wang, L.,Zou, F., Hei, X., Yang, D., Chen, D., Jiang, Q., \&Cao, Z. (2014a). A hybridization of teaching-learning-based optimization and differential evolution for chaotic time series prediction. Neural Computing and Applications,25(6), 1407-1422.

Wang, L., Zou, F., Hei, X., Yang, D., Chen, D., \& Jiang, Q. (2014b). An improved teaching-learningbased optimization with neighborhood search for applications of ANN. Neurocomputing,143(2), 231-247.

Xia, K., Gao, L., Li, W., \& Chao, K.M. (2014). Disassembly sequence planning using a simplified teaching-learning-based optimization algorithm. Advanced Engineering Informatics,28, 518-527.

Xiao, L., Zhu, Q., Li, C., Cao, Y., Tan, Y., \& Li L. (2014). Application of modified teachinglearning algorithm in coordination optimization of TCSC and SVC. Pattern Recognition, Communications in Computer and Information Sciences,483, 44-53.

Xie, Z., Zhang, C., Shao, X., Lin, W., \& Zhu, H. (2014). An effective hybrid teaching-learning-based optimization algorithm for permutation flow shop scheduling problem. Advances in Engineering Software,77, 35-47.

Xing, B., \& Gao, W-J. (2014). Teaching-learning-based optimization algorithm. Innovative Computational Intelligence: A Rough Guide to 134 Clever Algorithms. Intelligent Systems Reference Library, 62, 211-216.

Xu, Y., Wang, L., Wang, S., \& Liu, M. (2015). An effective teaching-learning-based optimization algorithm for the flexible job-shop scheduling problem with fuzzy processing time. Neurocomputing, 148, 26-268.

Yang, Z., Li, K., \&Guo, Y. (2014a). A new compact teaching-learning-based optimization method. Intelligent Computing Methodologies, Lecture Notes in Computer Science,8589, 717-726.

Yang, Z., Niu, Q., Xue, Y. \& Foley, A. (2014b). A self-learning teaching-learning based optimization for dynamic economic/environmental dispatch considering multiple plug-in electric vehicle loads.Journal of Modern Power Systems and Clean Energy, 2(4), 298-307.

Yildiz, A.R. (2013). Optimization of multi-pass turning operations using hybrid teaching learningbased approach. International Journal of Advanced Manufacturing Technology,66, 1319-1326.

Yu, K., Wang, X., \& Wang, Z. (2014a). An improved teaching-learning-based optimization algorithm for numerical and engineering optimization problems. Journal of Intelligent Manufacturing, doi:10.1007/s10845-014-0918-3.

Yu, G., Song, H., \& Gao, J. (2014b). Unmanned aerial vehicle path planning based on TLBO algorithm. International Journal on Smart Sensing and Intelligent Systems, 7(3), 1310-1325. 
Yu, K., Wang, X., \& Wang, Z. (2015). Self-adaptive multi-objective teaching-learning-based optimization and its application in ethylene cracking furnace operation optimization. Chemometrics and Intelligent Laboratory Systems, 146, 198-210.

Zhang, C., Li, K., Pei, L., \& Zhu, C. (2015a). An integrated approach for real-time model-based stateof-charge estimation of lithium-ion batteries. Journal of Power Sources,283(1), 24-36.

Zhang, Q., Yu, G., \& Song, H.(2015b). A hybrid bird mating optimizer algorithm with teachinglearning-based optimization for global numerical optimization.Statics, Optimization \& information Computing, 3(1), 54-65.

Zhang, Q., Yu, G., \& Song, H. (2014). Optimal approximation of linear systems using a teachinglearning-based optimization algorithm. Journal of Advances in Mathematics, 9(4), 2542-2552.

Zou, F., Wang, L., Hei, X., \& Chen, D. (2015). Teaching-learning-based optimization with learning experience of other learners and its application. Applied Soft Computing, doi:10.1016/j.asoc.2015.08.047.

Zou, F., Wang, L., Hei, X., Chen, D., \& Yang, D. (2014a).Teaching-learning-based optimization with dynamic group strategy for global optimization. Information Sciences,273, 112-131.

Zou, F., Wang,L., Hei,X., Chen,D., Jiang,Q., \& Li, H. (2014b). Bare-bones teaching-learning-based optimization. The Scientific World Journal, doi.org/10.1155/2014/136920.

Zou, F., Wang, L., Hei, X., Jiang, Q., \& Yang, D. (2013a).Teaching-learning-based optimization algorithm in dynamic environments. Swarm, Evolutionary and Memetic Computing, Lecture Notes in Computer Science, 8297, 389-400.

Zou, F., Wang, L., Hei, X., Chen, D., \& Wang, B. (2013b). Multiobjective optimization using teachinglearning-based optimization algorithm.EngineeringApplications of Artificial Intelligence,26, 12911300. 